\title{
El tratamiento documental del cartel cinematográfico
}

\author{
Rebeca FERNÁNDEZ MELLADO \\ rebe.fdez@gmail.com
}

Doctora en Ciencias de la Información

Recibido: $22 / 05 / 2014$

Aceptado: 15/06/2014

\section{RESUMEN}

Desde el punto de vista de las Ciencias de la Documentación, la conservación y la descripción del cartel de cine en los distintos archivos fílmicos juega un papel secundario con relación al tratamiento que reciben otro tipo de materiales que conforman también el patrimonio cinematográfico, como es el caso de la película.

En líneas generales, la descripción documental que se realiza de los carteles de cine en los centros que se ocupan de su tratamiento, se centra en la descripción de las características formales del cartel sin profundizar en la descripción de su contenido, atribuyéndole incluso características propias de la película que publicita y no del cartel. De esta realidad surge el objeto principal de esta investigación: el diseño de un modelo de tratamiento documental que sirva de base para la descripción de la forma y del contenido de los carteles cinematográficos.

Palabras clave: análisis documental, análisis semiótico mixto, argumentación publicitaria, cartel cinematográfico, cartel publicitario, Documentación audiovisual, Filmoteca Española, franquismo, patrimonio cinematográfico, tratamiento documental.

\section{Documentary Treatment of Movie Poster}

\begin{abstract}
From the viewpoint of Documentation science, the preservation and description of the movie poster found in various film archives plays a secondary role with respect with the treatment given other materials such as the film itself that comprise film heritage.

In general, the documentary description performed by treatment centers on movie posters focuses on the description of the physical characteristics of the movie poster without delving into the description of its contents. Even characteristics of the film being advertised are attributed to it and not to the poster itself. The main purpose of this research becomes apparent from the need for the design of a documentary model to act as a base for the physical description and content of movie posters.

Keywords: audiovisual documentation, documentary analysis, documentary treatment, mixed semiotic analysis, movie poster, poster, publicity argument, Spanish Film Archive.
\end{abstract}




\section{INTRODUCCIÓN}

El cartel cinematográfico ha acompañado a las películas desde los mismos orígenes de la cinematografía, siendo testigo de la evolución de los códigos estéticos y artísticos propios de cada época y tratando de llamar la atención de los espectadores para que dejasen de lado sus quehaceres cotidianos y entrasen en la sala a disfrutar del invento del cine. El cartel anunciador de la película ha servido asimismo para presentar distintos aspectos asociados al producto que publicita: las productoras responsables de las películas, los nombres de los directores y los actores que participan en los films y los premios y galardones obtenidos.

Desde el punto de vista de la Documentación, la conservación y descripción del cartel de cine en los distintos archivos fílmicos juega un papel secundario con relación al tratamiento que reciben otro tipo de materiales que conforman también el patrimonio cinematográfico. El producto cinematográfico central es la película y su tratamiento y conservación es el que ocupa principalmente el trabajo de las diferentes filmotecas.

La descripción documental que se realiza de los carteles de cine en las diferentes bibliotecas y filmotecas que se ocupan de su tratamiento, se centra fundamentalmente en la descripción de las características formales del cartel sin llegar a profundizar en la descripción de su contenido. Una práctica habitual es, de hecho, asociar a la descripción del cartel de cine las características propias de la película que publicita olvidando las propias del cartel. De esta realidad surge la necesidad de profundizar en el diseño de un modelo de tratamiento documental que analice y describa a nivel formal y de contenido, las diferentes características del cartel cinematográfico.

\section{EL CARTEL CINEMATOGRÁFICO}

\subsection{El cartel de cine: concepto, características y funciones}

El cartel cinematográfico nace a finales del siglo XIX y tiene su origen en la invención misma del cine y en su desarrollo como espectáculo público. El cartel publicitario vivía sus años de máximo esplendor, por lo que no es extraño que la industria del cine lo emplease como medio principal para publicitar sus películas. Nace de esta manera un nuevo tipo de cartel: el cartel cinematográfico que, como se verá más adelante, cuenta con unas funciones y unas características propias que lo diferencian de otros tipos de carteles publicitarios.

Antes de profundizar en la definición y en las características específicas del cartel de cine es importante conocer los conceptos de cartel y de cartel publicitario. Por su parte, se puede decir que un cartel es:

Una lámina de papel $\mathrm{u}$ otro material, impreso a una cara, generalmente de gran tamaño, compuesto por imagen, texto o por ambos a la vez y que está destinado a exhibirse en lugares públicos, 
transitados especialmente por viandantes, con claros fines informativos y/o publicitarios.

El cartel publicitario por su parte, surge como un tipo específico de cartel y puede definirse como:

Una lámina generalmente de papel y de gran tamaño, impresa a una cara, compuesta por imagen, texto o por ambas a la vez y que se erige como un sistema de comunicación intencional y pagado, cuyo fin es dar a conocer un producto, servicio o idea para informar o influir en su compra o aceptación.

El cartel de cine coincide con el cartel publicitario en su finalidad difusora de productos, siendo la película el producto concreto a difundir. La Ley de Cine aprobada el 28 de diciembre de 2007 en España define en su artículo $4^{\circ}$, apartado a) a la película cinematográfica como:

Toda obra audiovisual, fijada en cualquier medio o soporte, en cuya elaboración quede definida la labor de creación, producción, montaje y posproducción y que esté destinada, en primer término, a su explotación comercial en salas de cine. Quedan excluidas de esta definición las meras reproducciones de acontecimientos o representaciones de cualquier índole (BOE, 312, p. 53689).

Teniendo en cuenta las definiciones de cartel publicitario y de película cinematográfica se puede decir que un cartel de cine es:

Un anuncio publicitario, impreso a una cara, en una lámina generalmente de papel y de gran tamaño, compuesto por imagen, texto o por ambos a la vez y diseñado para promocionar una película cinematográfica con el fin de informar sobre ella e influir en el público para su visionado.

El cartel de cine se justifica por la existencia misma de la película que publicita a la que queda ligado estrechamente. Sin embargo, no deja de ser, como afirma Perales Bazo (2007, p. 60), un texto autónomo que se emplea para modificar la conducta del individuo a través de una serie de signos visuales y textuales.

El cartel de cine posee un doble valor informativo: por un lado informa sobre el estreno o la proyección en los cines de una película en cuestión y, por otro, como señala Collado Alonso (2012, p. 64), informa sobre las características de la propia película (intérpretes, director, personal técnico, empresas de producción y distribución, etc.).

Una de las características que Pérez Perucha (1986, pp. 9-10) señala como diferenciadora del cartel de cine es que no necesita revelar las cualidades del producto -como pasa en el cartel publicitario-, dado que, generalmente, los consumidores ya las conocen y las valoran de forma positiva.

Las formas de difusión del cartel de cine también son características de su clase ya que no se ciñen exclusivamente a los cauces de difusión estándar del cartel publicitario. Pérez Perucha (1986, p. 12) contempla dos formas de difusión que resultan específicas del cartel cinematográfico: 
1. La propia sala de cine, donde el espectador puede observar el cartel de una forma más reposada favoreciendo la decisión de asistir al espectáculo y recibiendo a su vez más información sobre el mismo.

2. Mediante la reformulación de sus dimensiones materiales, es decir, con la creación de los programas de mano a imagen del cartel, convirtiéndolo de esta forma en un objeto de consumo privado y de coleccionismo.

Es importante situar el cartel anunciador de la película muy cerca de las taquillas para poder influir en el espectador en el momento mismo en que hace la elección de la película (y más hoy día, con la creación de las multisalas).

Aunque han pasado muchos años desde la aparición del primer cartel de cine, sigue siendo hoy día el material gráfico más importante de los que se destinan a promocionar una película, aun teniendo que competir con otros productos publicitarios como, por ejemplo, el tráiler de la película. Como señala Rodríguez Tranche (1996):

El cartel sigue siendo la imagen más trabajada de una película: condensa la idea de conjunto, aporta la información más elocuente, ocupa el espacio urbano (adaptándose a las más variadas superficies) y la propia sala de exhibición y, en definitiva, puede circular con mayor facilidad y alcance que ningún otro procedimiento de promoción. (p. 22).

El cartel cinematográfico debe conseguir realizar una auténtica labor de síntesis de los elementos más representativos de la película que anuncia, utilizando para ello los recursos que están a su alcance: las imágenes y los textos.

El cartel posee una serie de funciones que cumple como soporte de imagen en la sociedad de consumo. Estas funciones aparecen definidas en la obra El afiche en la sociedad urbana de Abraham Moles (1976): función de información, función de persuasión, función educativa, función ambiental, función estética y función creadora.

El cartel cinematográfico por su parte cumple, según Perales Bazo (1999), con cuatro de las seis funciones propuestas por Moles. Estas funciones otorgan al cartel cinematográfico el valor publicitario específico de su clase:

1. La función de información: cumple con el objetivo de relacionar a un emisor con un receptor a fin de dar a conocer la existencia de la película que se pretende difundir. En este proceso el cartel de cine, además de dar a conocer el producto, pretende influir en el receptor de manera que modifique su elección frente a la variada oferta de la cartelera.

Para cumplir con la función de información debe existir un equilibrio entre los elementos que componen el cartel (texto e imagen), siendo el texto, en este caso, el que más garantiza la función de información. El motivo, según Perales Bazo (1999, p. 43), es que la imagen posee un valor de iconicidad muy superior al de otros signos pero tiene también un alto valor polisémico. Esto hace imprescindible la dualidad imagen-texto, para evitar imprecisiones en la captación del contenido del cartel además de para ofrecer otras 
informaciones que la imagen no puede aportar por sí misma. Hay que tener en cuenta la influencia del star system en el cartel de cine ya que limita la representación de información en el cartel a las imágenes de los actores o de alguna escena de la película.

2. La función de persuasión: el cartel de cine no se limita a elogiar las bondades de una película. Los encargados de la campaña publicitaria de un film no desconocen las dificultades del mercado ni el hecho de que su película tendrá que competir con productos que tienen exactamente el mismo precio que el suyo.

La función del cartel de cine es difundir la película que anuncia, haciéndose hueco y sobresaliendo en el complejo espacio comercial en el que se mueve. Es necesario atender al perfil del espectador al que va dirigido un film a la hora de diseñar su cartel, asignándole ciertos valores simbólicos que eviten la confusión en cuanto al contenido de la película (por ejemplo, no acudir a la caricatura para anunciar un melodrama).

3. La función ambiental: al igual que el cartel publicitario, el cartel cinematográfico se integra en la sociedad para formar parte de su paisaje urbanístico. La multiplicación de anuncios, en este caso de carteles anunciadores de películas, puede generar rechazo en el receptor por la acumulación de mensajes que recibe, lo que obliga a las distribuidoras a conseguir los mejores lugares para promocionar sus películas.

4. La función urbana ${ }^{1}$ : en los estudios sobre el cartel de cine surge con frecuencia el interrogante de si debe de ser tratado como un modo de expresión artística o someterse exclusivamente a criterios publicitarios. En torno a esta cuestión surgen dos tendencias diferenciadas: lo que opinan que el cartel de cine debe atender por encima de todo a criterios de promoción y los que opinan que, por el contrario, lo más importante es atender a sus cualidades creativas y estéticas.

Ambas tendencias no deben de ser excluyentes entre sí. El valor estético del cartel resulta fundamental a la hora de hacer llegar el mensaje al público: un cartel estéticamente cuidado calará de forma más honda y permanente en aquel que lo observa. Por otro lado, no se debe descuidar la naturaleza publicitaria del cartel de cine por atender a criterios puramente estéticos. Es por ello que debe tratarse a cada elemento que compone el cartel (imagen y texto) de manera concienzuda, para lograr que éste cumpla con su misión de promoción y de difusión.

${ }^{1}$ La función urbana propuesta por Perales Bazo (1999) hace referencia directa a la función estética planteada por Moles (1976). 


\subsection{La estructura semiótica mixta del cartel cinematográfico}

Bordwell, Staiger y Thomson (1997, p. 107) señalan en su trabajo sobre el cine clásico de Hollywood que: "uno de los principales mecanismos que establecieron los estándares de calidad cinematográfica fue el discurso publicitario."

La publicidad resulta fundamental para acercar al consumidor las posibilidades del producto que se pretende introducir en el mercado. Su asociación al cine, como se ha comentado, no es nueva: nace a la par que el invento del cinematógrafo a finales del siglo XIX. Sin embargo, la publicidad como tal hunde sus raíces en tradiciones más antiguas y evoluciona a partir del libro impreso y de la ilustración artesanal.

Bajo esta premisa, Adam y Bonhomme $(2000$, p. 73$)$ señalan que el discurso publicitario se presenta desde sus orígenes como: "una estructura semiológica mixta, un híbrido laxo e inestable, debido a las aptitudes de dosificación que permite entre el texto y la imagen $\mathrm{y}$, sobre todo, a la diversidad de sus componentes."

En este sentido, los autores citados afirman que el discurso publicitario se vale de una serie de constituyentes que aportan las bases significantes sobre las que se sustentan los significados info-persuasivos que aseguran la eficacia argumentativa de la publicidad. La publicidad escrita puede decirse que se basa en un doble sistema icónico y verbal, de principios antagónicos.

Adam y Bonhomme (2000, pp. 73-84) organizan la estructura semiótica mixta de la publicidad escrita en torno a tres significantes: la imagen (significante icónico), el texto (significante lingüístico) y el logotipo (significante compuesto).

\subsubsection{El significante icónico: la imagen}

Aunque desde un punto de vista histórico la imagen aparece en la publicidad después que el texto, constituye desde el punto de vista semiológico, el componente más importante del discurso publicitario. Adam y Bonhomme (2000, p. 74) señalan que el terreno del icono se centra principalmente en lo visual (en la imagen) y le asignan dos propiedades paradójicas:

1. Propiedad intransitiva: la imagen muestra lo representado tal cual es, lo que favorece su memorización.

2. Propiedad transitiva: mientras que el lenguaje se limita a remitir a lo que quiere describir, la imagen siempre lo reproduce. Es cierto que en publicidad no siempre la imagen es totalmente fiel a lo representado, pero sí da la impresión de evocarlo fielmente.

La imagen en el cartel cinematográfico supone un estímulo más fuerte que el texto gracias a, como señala Gómez Pérez (2002, p. 209), su poder de atracción y de seducción (por su composición, colorido, etc.).

El texto constituye un estímulo más débil pero fundamental a la hora de componer un buen cartel resultando decisivo a la hora de aclarar el sentido del 
mensaje que se pretende transmitir. En palabras de Alcacer Garmendia (1991, p. 12): "en el sistema icónico-literario del cartel, el texto, en relación a la posible ambigüedad de las imágenes, aclara y fija el sentido, o lo refuerza dándole mayor alcance, o lo matiza ampliamente."

Esta idea de imagen comentada es expresada por Moles (1985, p. 91) en su definición de cartel: "sistema de comunicación de masas por difusión basada en una imagen comentada, plana, pegada sobre una superficie expuesta a las miradas de los transeúntes."

El espectador juega un papel fundamental en la recepción del mensaje publicitario. El cartel se traduce en una imagen fija y no en movimiento como en el caso de otros productos publicitarios filmados. Es por ello que el tiempo de exposición, en el caso del cartel publicitario, está en manos del espectador, que puede recurrir a la imagen el tiempo que estime necesario para profundizar sobre ella y fijarla en su memoria.

Desde el punto de vista de la práctica comercial, la imagen -y por extensión el cartel de cine-, hace de intermediaria entre el publicista y el espectador. Para conseguir plenamente la eficacia publicitaria es necesario eliminar del cartel de cine la condición de mediador entre el producto y el público. Willis GarcíaTalavera (2002, p. 156) considera que esto se consigue "gracias a la mágica distorsión de la realidad que ofrece el mundo del cine y todos los objetos relacionados -programas, carteles, postales, fotografías, etc.- que, a modo de satélites, giran en torno a él."

En la composición del cartel de cine se deben de emplear imágenes que sugieran o evoquen de alguna manera el universo cinematográfico actuando, como apunta Rodríguez Tranche (1994, p. 138), como principio por condensación en clave metonímica. Por ello el cartel de cine se convierte en un género específico cuyo referente no es un objeto o una idea, sino otra imagen.

En cuanto a las técnicas empleadas para la representación de imágenes en los carteles de cine, se puede decir que durante los primeros años del cinematógrafo se sigue con la influencia artística y pictoricista del Art Nouveau hasta asumir elementos introducidos por las diferentes vanguardias (como por ejemplo el fotomontaje).

A partir de los años veinte se comienza a notar la influencia de la propia técnica cinematográfica (utilización del plano en la composición, yuxtaposición de elementos, etc.). De esta influencia se derivan, en opinión de Rodríguez Tranche (1994, p. 139), dos líneas de composición del cartel cinematográfico que se han conservado hasta hoy:

1. Interpretación libre del tema de la película y representación en el cartel a través de motivos alegóricos con una composición única: este tipo de cartel está influido, entre otros, por las vanguardias artísticas y se ve bien representado en el cartel de cine alemán de las décadas de 1920 y 1930.

2. Representación de motivos concretos extraídos de la película: este tipo de cartel es más realista y está íntimamente relacionado con el fenómeno de 
star system. Predomina en este modelo el retrato de las estrellas desde diferentes planos y la utilización de imágenes diegéticas o escenas de la película a modo de complemento.

El star system condiciona sustancialmente la composición de carteles cinematográficos por la importancia que cobran las estrellas como reclamos publicitarios a partir de los años veinte. Para la recreación de la figura de la estrella, Perales Bazo (1999, pp. 161-162) recopila una serie de situaciones comunes que se dan en la representación de estrellas en los carteles de cine, con independencia del género de la película y del cartelista que realice el cartel:

- Representación de la figura del protagonista como tema central de la composición y su relación con la estrella que lo interpreta. Estrella y personaje se combinan en un solo elemento que supone la base publicitaria de la película.

- Representación del rostro de la estrella como imagen central del cartel, sin que ésta evoque en ningún caso al personaje que se representa.

- Utilización de fondos neutros o de un solo color que muchas veces se fundían con la imagen del protagonista.

- Representación del personaje en plano general. Se utilizaba este recurso normalmente cuando el rostro de la estrella no contribuía a reforzar el tema de la película.

Partiendo de estas cuatro situaciones, Perales Bazo (1999, pp. 162-164) establece la siguiente clasificación del contenido visual del cartel de cine basado en el fenómeno del star system:

- Contenido visual compuesto por motivos o escenas extraídos directamente de la película.

- Contenido visual centrado en actores o actrices cuya imagen no referencia directamente el contenido de la película o lo hacen de una forma muy sutil.

- Contenido visual centrado en el rostro de la estrella.

- Contenido visual centrado en el busto de la estrella (para estimular al espectador al poseer la imagen mayor riqueza informativa).

\subsubsection{El significante lingüístico: el texto}

A diferencia de lo que ocurría con la imagen, con el texto el signo se distancia de su referente para acercarse a la abstracción y a lo arbitrario. Mientras que la imagen reproduce directamente lo que quiere describir, el texto se limita a remitir al objeto de descripción.

De acuerdo con la clasificación de Adam y Bonhomme (2000, p. 75-82), el significante lingüístico o texto puede dividirse para su análisis en tres constituyentes:

1. El constituyente mínimo (la marca): concepto general de marca, se subdivide a su vez en la marca de la firma (marca o empresa responsable del producto) y en el nombre del producto que se esté publicitando. 
2. El constituyente condensado (el eslogan): entendido como una frase breve de carácter publicitario que sirve para atraer la atención del receptor del mensaje publicitario. El eslogan se divide en dos tipos: el gancho (headline), situado al inicio de un anuncio, se caracteriza por ser un elemento llamativo con un aspecto atrayente de impacto inmediato en el receptor; y la frase de asiento (base-line), situada al final del anuncio y que detalla generalmente la divisa de la marca, la promesa que hace al consumidor. Se caracteriza por su contenido genérico y su aspecto duradero.

3. El constituyente expandido (lo redaccional): ofrece un desarrollo predicativo más o menos extendido y con una estructura abierta. Como señalan Adam y Bonhomme (2000, p. 82): "en el plano formal, proporciona el componente digital por excelencia del anuncio, con su despliegue sintagmático, su progresión en argumentos y en contra-argumentos, su articulación en secuencias y sub-secuencias, materializadas o no por una segmentación tipográfica en párrafos". A la vista de lo expuesto, se puede adivinar que este constituyente no resulta especialmente representativo para el caso del cartel de cine.

En los primeros años del cartel cinematográfico, los carteles de cine estaban orientados a promocionar el invento del cine y no tanto a hacer promoción de las proyecciones que se hacían. En estos primeros carteles, el texto que aparecía era generalmente el del título del invento. Estos carteles se colgaban en las fachadas de los primeros cines y se complementaban con unos carteles tipográficos de pequeño tamaño en los que se nombraban las películas que se iban a proyectar en la sala durante el periodo que se estipulase.

A partir de los años veinte, coincidiendo con los primeros años del star system, el componente textual del cartel comienza a cobrar importancia y empiezan a aparecer reflejados los nombres de estrellas, de directores, de la empresa productora y hasta de técnicos que participan en la realización de la película.

En los años treinta será cuando comiencen a darse grandes cambios en la composición del cartel y a buscarse, como apunta Collado Alonso (2012, p. 70), un mayor equilibrio entre el dibujo y el propio texto.

Los textos que habitualmente aparecen en el cartel de cine se pueden agrupar en dos categorías:

1. Los que remiten a elementos propios de la película publicitada: título, reparto artístico, director, técnicos, empresas participantes (generalmente productora, distribuidora $\mathrm{y}$, en ocasiones, el nombre del estudio de rodaje ${ }^{2}$ ) y el eslogan.

${ }^{2}$ Este elemento es muy característico de los carteles de cine español de la década de los cuarenta y cincuenta. 
2. Los que remiten a elementos propios del cartel: firma del cartelista, nombre y dirección del taller donde se imprime el cartel y el depósito legal ${ }^{3}$.

De entre los textos que remiten directamente a la película caben destacar por su importancia en la composición del cartel cinematográfico: el título y el reparto de estrellas.

El título es la palabra o la frase que da a conocer el nombre de la película y, por lo tanto, es el elemento textual más importante del cartel. A su reconocida importancia se le debe que su representación sea la más llamativa y de mayor tamaño de entre los textos que componen el cartel y se caracteriza, en general, por su representación horizontal. Como señala Perales Bazo (1999, p. 96), el título es el encargado de relacionar con absoluta precisión el cartel y el producto que anuncia. Los dos objetivos que persigue son: por un lado, denominar e identificar la película y, por otro, darle la mayor difusión posible.

Una característica del texto en los carteles cinematográficos es su capacidad figurativa. Mediante la manipulación del color, tamaño y forma de los caracteres, los textos se asocian a determinados objetos o temas relacionados con la película que anuncian. Es por ello que Gómez Pérez (2002) afirma que:

El texto se convierte en muchos carteles cinematográficos en un estímulo visual, comunicando como tal. Esta transformación se realiza, en infinidad de ocasiones, influida por la temática de la película, las formas de las imágenes del cartel, el significado del título. (p. 213).

Esta capacidad visual aparece reflejada fundamentalmente en el título de las películas y, en muchas ocasiones, aporta una rica información sobre la temática del film. Aunque no de forma totalmente generalizada, es común asociar una película al género al que pertenece por el formato de la tipografía del título del cartel.

Así, en géneros como el épico, el título suele estar representado con grandes caracteres que simulan moles de piedra. En el caso del western, el título aparece representado con texturas que recuerdan al lejano oeste (por ejemplo madera atravesada por flechas). El musical suele dar movilidad a sus textos creando títulos verticales, oblicuos, ondulantes o curvos de llamativos colores. En el género histórico, las letras suelen simular las propias de la época en que se desarrolla la película. El género de terror, por su parte, es de los que más trabaja la tipografía de sus títulos para diferenciar claramente la temática de la película. Los colores que más se emplean en la tipografía de este género son el rojo (que se asocia a la sangre), el verde y el amarillo (asociados al miedo y a la muerte respectivamente).

Otro tipo de texto que se asocia directamente con elementos de la película es el que se emplea para representar el nombre de las estrellas del reparto. Por orden de importancia se puede considerar, gracias al star system, el segundo elemento

${ }^{3}$ El depósito legal se aprueba en España por Decreto de 23 de diciembre de 1957 (BOE, 17, pp. 104-106). 
textual más importante del cartel cinematográfico. Los nombres de las estrellas, al igual que los nombres de directores e incluso de empresas productoras, son un elemento informativo aunque bien es cierto que, en muchos casos, estos nombres suponen un reclamo publicitario de importancia capital a la hora de promocionar una película.

El fenómeno del star system resultó decisivo en la representación de nombres de estrellas en los carteles, llegando a suponer esto un verdadero conflicto entre los artistas de un film, que luchaban junto con sus representantes por una posición privilegiada de su nombre en el cartel. Perales Bazo (1999, p. 16) enumera una serie de acuerdos que habitualmente se toman con los actores a fin de evitar posibles desavenencias por la representación de su nombre en la publicidad:

- Si el reparto está compuesto por dos o más estrellas de igual o similar categoría, la tipografía utilizada para representar los nombres de los actores será idéntica en tamaño, posición y en aspectos cromáticos.

- Si el reparto está formado por estrellas de igual categoría, pero el tratamiento es diferente entre ellos, el cromatismo y el tamaño de la fuente es idéntico pero varía la posición (al más importante aparecerá en una posición aventajada con respecto al resto).

- Si el reparto principal está formado por una sola estrella, su nombre será representado en grandes caracteres.

- Cuando exista la colaboración extraordinaria de una estrella (en caso de actores muy populares), su nombre se representa en grandes dimensiones encabezando el reparto de la película.

La representación de las empresas que participan en una película (productora, distribuidora, estudios de rodaje y de sonido) también son un elemento importante de reclamo publicitario. Estas empresas suelen aparecer representadas por su logotipo, elemento icónico-textual del que se hablará más adelante.

El eslogan constituye un elemento de reclamo publicitario importante que predomina en carteles de grandes dimensiones. Hoy día la utilización de un eslogan en los carteles es un recurso bastante común para conseguir atraer la atención del espectador en potencia. En los primeros años del cine se da de forma esporádica y con reclamos no demasiado elaborados que hacían alusión a las estrellas o al tema de la película. El eslogan de carácter más comercial comienza a popularizarse en Estados Unidos en la década de los cincuenta y en España a mediados de los setenta. Otros textos frecuentes son los relacionados con los premios concedidos a una película que funcionan en cierto modo como reclamo o eslogan de promoción.

Los inventos relacionados con el cine han tenido su espacio a menudo en el cartel cinematográfico, apareciendo textos que promocionaban avances como el Technicolor o el Cinemascope. Un ejemplo es el texto que aparece en el cartel de la reposición de la película El Escándalo de J.L. Sáez de Heredia de los años cincuenta (v. figura 1). 
La segunda categoría de textos que aparecen en el cartel de cine es la que recoge aquellos que representan elementos que guardan relación directa con el cartel y no con la película que anuncia: la firma del cartelista, el nombre del taller o imprenta y el número de control del documento (en el caso español es el depósito legal).

La firma del cartelista no siempre aparece impresa en el cartel. Los motivos son diversos: en el caso de los carteles españoles, es frecuente encontrar algunos sin firma debido muchas veces a la imposición de la misma distribuidora; en otras ocasiones, sobre todo en los comienzos del cine, si el cartelista era un pintor de renombre, no firmaba los carteles por considerarlos una forma de arte "de segunda"; otro motivo que surge tras la Guerra Civil, es el miedo a las represalias por parte de artistas que habían trabajado en zona republicana antes del conflicto y que preferían no dejar su nombre impreso en los carteles.

Hay ocasiones en que el diseño del cartel corre a cargo de una empresa de publicidad o de un equipo de artistas, por lo que la firma del cartel no corresponde a una persona sino a una firma conjunta ${ }^{4}$ o un logotipo de empresa.

Otro elemento textual que aparece en los carteles españoles es el depósito legal, que comienza a imprimirse de forma obligatoria desde su entrada en vigor en 1957. El nombre de la imprenta, acompañado generalmente de su dirección postal, aparece también impreso en el cartel desde los primeros anuncios del invento del cine.

${ }^{4}$ Por ejemplo, en España, trabajan grupos como MCP (Martí, Clavé y Picó) o WORG (Wila, Olcina, Ramírez y García). 
Figura 1. Cartel de la película El Escándalo (ca. 1950). Fuente: Fondos de Filmoteca Española.

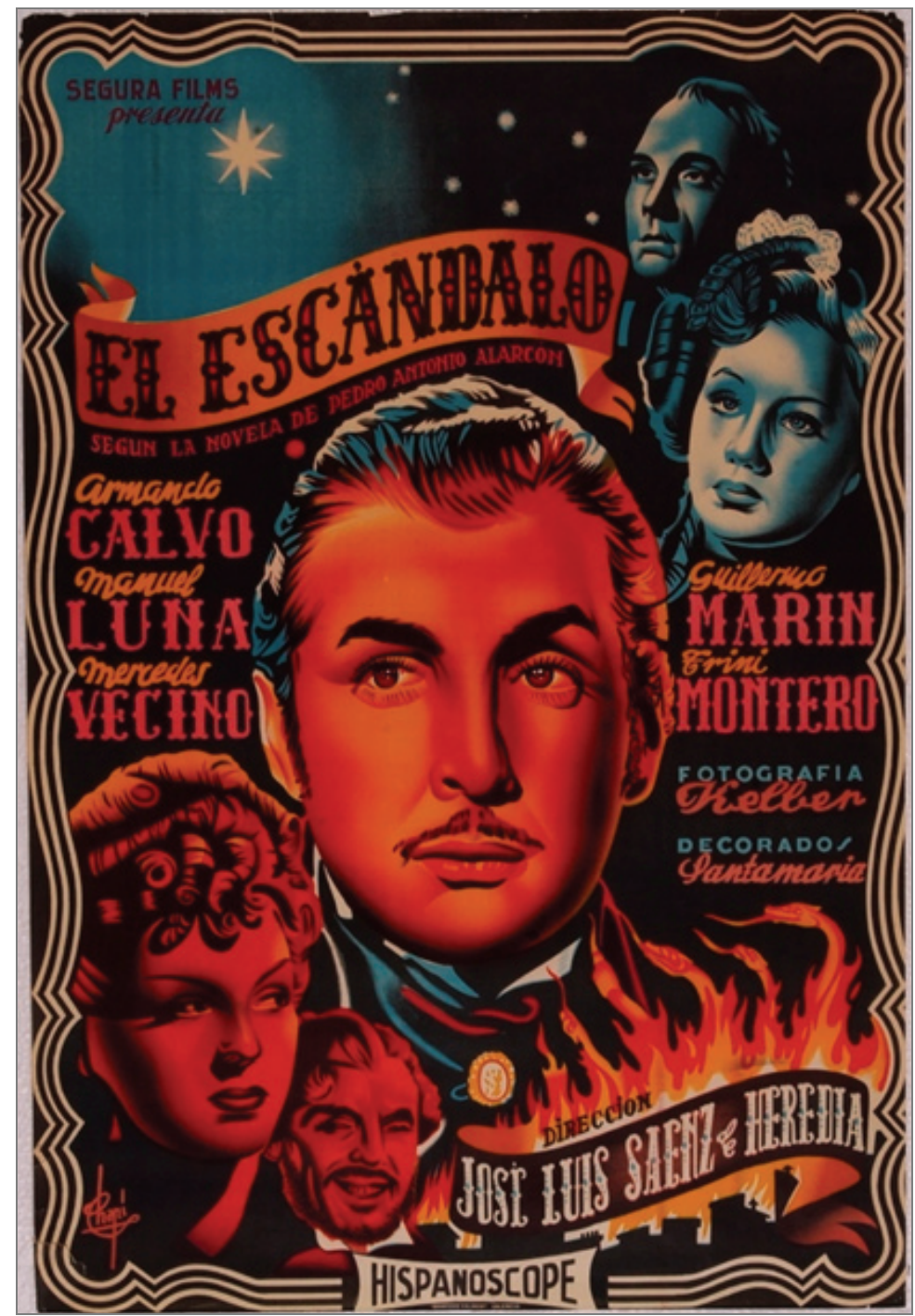

\footnotetext{
${ }^{5}$ Cartel diseñado para la reposición en los años cincuenta de la película original de 1943.
} 


\subsubsection{El significante compuesto: el logotipo}

El logotipo es un elemento que oscila entre la imagen y el texto, entre el lenguaje y el diseño, cuya función principal es que se asocie a él el nombre de una marca comercial. Se pueden encontrar logotipos formados a partir de una imagen únicamente, logotipos formados por imagen y texto o logotipos textualesfigurativos ${ }^{6}$.

Adam y Bonhomme (2000, p. 84) establecen dos funciones argumentativas para los logotipos:

- Función de apropiación inmediata de la marca: verdadera imagen de empresa que debe ser identificable y memorizable de un solo golpe de vista.

- Función de valorización del concepto de la marca: a través del logotipo debe ser reconocible la actividad de la marca a la que representa.

En los carteles de cine, los logotipos que aparecen de forma habitual son los que representan a las empresas implicadas en el proceso de producción y distribución de una película. Los más comunes en los carteles españoles de cine son los de la productora, la distribuidora y los estudios de rodaje (para carteles de cine español).

En algunas ocasiones, como ya se ha comentado, el responsable de la elaboración del cartel, no es un cartelista entendido como persona fisca sino que es una empresa. En estos casos es frecuente que la empresa publicitaria plasme su logotipo en el cartel de cine.

\section{EL TRATAMIENTO DOCUMENTAL DEL CARTEL DE CINE}

\subsection{El cartel de cine como documento}

Del estudio de la estructura semiótica mixta del cartel cinematográfico, puede extraerse la conclusión de que el cartel de cine es un documento que posee unas características formales propias que se diferencian sustancialmente de las características de la película que anuncia.

Desde una perspectiva etimológica, estudiada por Sagredo e Izquierdo, López Yepes y Martínez Comeche (Rodríguez Bravo, 2002, p. 77), el término documento, proviene del latino documentum, que a su vez deriva del verbo doceo (enseñar o instruir), con el sufijo -mentum, que aporta un sentido instrumental. Así el término documentum designa en latín clásico el medio utilizado para ejecutar la acción aludida por el verbo al que acompaña, es decir, sería aquello que es utilizado para la transmisión de conocimientos. Ya el latín clásico había instaurado la voz documentum con las dos grandes acepciones que poseerá el vocablo a lo largo de la historia (transmisión de conocimiento y confirmación de hechos).

${ }^{6}$ Se entiende por logotipos textuales-figurativos, aquellos formados por textos cuyos caracteres forman o recuerdan a elementos visuales o imágenes. 
Martínez de Sousa, en su Diccionario de Bibliotecología y Ciencias afines (2004), da cabida en la primera acepción de la definición de documento a expresiones manifestadas en todos los soportes: "expresión del pensamiento (biografía, relato, texto laudatorio, funerario, testamentario, etc.) por medio de signos gráficos (letras, dibujos, pinturas, etc.) sobre un soporte (piedra, pergamino, papel, lienzo, película, cinta, etc.)."

En definitiva, un documento es entendido como aquel objeto que transmite información, independientemente del soporte en que se encuentre. Ya en los orígenes de la Documentación como ciencia aparecen alusiones a documentos en soportes diferentes al papel impreso con texto escrito. En El Tratado de Documentación de 1934, Paul Otlet da cabida a diferentes tipos de soportes a los que denomina sustitutos del libro:

Los nuevos procedimientos permiten que el libro alcance los resultados que pretende (información, comunicación) poniendo en marcha otros medios además de él mismo. Pero también existe una elaboración adquirida, buscada o vislumbrada de los nuevos tipos de documentos. Por esta doble razón se les debe de reservar a los sustitutos del libro un lugar importante dentro de la documentación... el libro sólo es el medio: no es un fin. Existen otros medios y poco a poco ofrecen más que el libro y lo sustituyen. (1996, pp. 216-217).

Otlet clasifica al cartel dentro de los documentos gráficos que no son obras impresas y dice de él que:

Es uno de los tipos de un género constituido por las vistas murales en general... están destinados a llamar la atención y a ser ventanas abiertas de la actividad de los hombres y de los bellos paisajes. Los carteles son esquemas, símbolos: llaman la atención mediante una ilustración que debe evocar objetos, productos, parajes. (1996, p. 196).

Según las definiciones aportadas, se puede decir que un cartel cinematográfico es un documento que aporta información, que posee un soporte independiente al de la película que publicita y posee una intención comunicativa propia, luego es un documento que además cuenta con unas características específicas $\mathrm{y}$, en consecuencia, deberá ser tratado como documento autónomo.

\subsection{El cartel de cine dentro del patrimonio cinematográfico}

Desde el punto de vista de las Ciencias de la Documentación, el cartel de cine ha de recibir un tratamiento independiente y ajustado a su clase, aunque sin perder de vista el vínculo inseparable que mantiene con la película que publicita y que le lleva a formar parte junto con ésta, del conjunto más amplio de documentos que se generan en el proceso de producción y distribución de una película y que conforman el patrimonio cinematográfico. 
En La imagen rescatada: recuperación, conservación y restauración del patrimonio cinematográfico (Filmoteca Generalitat Valenciana, 1991) se exponen las características del citado patrimonio cinematográfico:

El patrimonio cinematográfico es un todo. La gran variedad de documentos y materiales que van surgiendo en el proceso de producción y difusión de una película deben ser conservados, restaurados y catalogados. No sólo constituyen el testimonio histórico de una época, sino que clarifican también las relaciones entre las diferentes ramas artísticas, técnicas, industriales y económicas que intervienen en la realización y el disfrute de la obra cinematográfica. Junto con las películas, las filmotecas se encargan de conservar desde los guiones originales, los planes de rodaje y el material gráfico que se produce durante la filmación de una película, hasta los antiguos programas de mano, carteles publicitarios y guías de distribución, sin olvidar las diferentes máquinas de filmación y proyección. (p. 37).

Como se puede observar, la definición incluye dentro del patrimonio cinematográfico a todo el material gráfico (carteles, programas de mano, etc.) que se produce para la difusión de las películas.

Por otro lado, UNESCO, en un primer borrador del Proyecto de Convención para la Protección del Patrimonio Audiovisual Europeo (Edmondson, 2004), define lo que denomina patrimonio audiovisual:

El patrimonio audiovisual comprende las películas producidas, distribuidas, difundidas o puestas de otro modo a disposición del público... la película se define como una serie de imágenes en movimiento fijadas o almacenadas en un soporte (cualquiera que sean el método de grabación y la naturaleza del soporte utilizado en la grabación inicial o subsiguientes), con o sin sonido acompañante, que al ser proyectada crea una impresión de movimiento. (p. 24).

En esta primera aproximación no se contempla al cartel dentro del patrimonio audiovisual, tan solo comprende las películas. Un desarrollo en la definición incluye dentro de patrimonio audiovisual más soportes, entre ellos, el cartel. Así, la UNESCO establece (Edmondson, 2004, pp. 24-25) que el patrimonio audiovisual abarca, sin estar limitado a ello, los siguientes soportes:

- Las grabaciones sonoras, radiofónicas, cinematográficas, de televisión, en vídeo y otras producciones que incluyen imágenes en movimiento $\mathrm{y} / \mathrm{o}$ grabaciones sonoras, estén o no destinadas principalmente a la difusión pública.

- Los objetos, materiales, obras y elementos inmateriales relacionados con los medios audiovisuales, desde los puntos de vista técnico, industrial, cultural, histórico u otro; comprenden los materiales relacionados con las industrias cinematográfica, radiotelevisiva y de grabación, como las publicaciones, los guiones, las fotografías, los carteles, los materiales 
publicitarios, los manuscritos y creaciones diversas entre las que se cuentan los vestuarios y los equipos técnicos

- Los conceptos como la perpetuación de técnicas y entornos caídos en desuso asociados con la reproducción y presentación de esos medios.

A lo que UNESCO denomina patrimonio audiovisual quizás sería más acertado denominarlo patrimonio cinematográfico. En este sentido, Valle Gastaminza (2007) establece esta definición de documento audiovisual:

Obras que comprenden imágenes reproducibles y/o sonidos incorporados a un soporte cuya grabación, transmisión, percepción y comprensión requiere generalmente de algún equipo tecnológico, cuyo contenido visual y/o sonoro tiene una duración lineal y cuyo propósito es la comunicación de ese contenido.

La diferencia entre el patrimonio cinematográfico y patrimonio audiovisual reside en que el audiovisual abarca un campo más amplio, en el que se incluye la radio y la televisión que siguen caminos muy diferentes a los del cine.

\section{TRATAMIENTO DOCUMENTAL DEL CARTEL CINEMATOGRÁFICO}

\subsection{Principios y estándares de catalogación de documentos}

Hace ya más de cincuenta años, la Federación Internacional de Asociaciones de Bibliotecarios y Bibliotecas (IFLA) inició una revisión de los fundamentos teóricos y prácticos de catalogación a nivel internacional. En un congreso internacional que tuvo lugar en París en 1961, se llegó a una serie de acuerdos para la unificación de criterios de catalogación conocidos como Los Principios de París.

Más tarde, en la Reunión Internacional de expertos de Catalogación celebrada en 1969 en Copenhague, comenzó a trabajarse en un segundo objetivo: establecer una normativa internacional para la descripción de forma y de contenido de los registros bibliográficos. Nacen así, en 1971, las primeras normas de Descripción Internacional Normalizada para Publicaciones Monográficas: las conocidas normas ISBD.

Las normas ISBD significaron la base para el desarrollo de diversos códigos adaptados a nivel nacional e internacional. En el caso español, sirvieron para desarrollar las Reglas de Catalogación, cuya primera versión vio la luz en 1985.

Durante estos primeros años de trabajo, a la vez que se llegaban a acuerdos y se desarrollaban estándares de catalogación, el medio de aplicación de las ISBD cambió radicalmente. El informe final de la IFLA sobre Requisitos Funcionales de los Registros Bibliográficos (2004, p. 28) establece tres factores clave que intervinieron en el cambio producido en este periodo:

- Introducción y desarrollo de sistemas automatizados para la creación y proceso de los datos bibliográficos.

- Crecimiento a gran escala de las bases de datos nacionales e internacionales. 
- Desarrollo de programas de catalogación compartida que favorecieran el intercambio de registros a nivel nacional e internacional, para lo que se hacía necesario el desarrollo de códigos comunes de catalogación.

A lo largo de las últimas décadas del siglo XX, se trabajó para lograr el control bibliográfico, desarrollando una serie de herramientas que favoreciesen la recuperación y el acceso a la información. Algunas de estas normas son las ya citadas ISBD, el formato MARC (MAchine-Readable Cataloging) o las AACR (Anglo American Cataloguing Rules).

Como señalan Picco y Ortiz Repiso (2012, p. 148), ahora el espectro ha cambiado: no solo se puede hablar de un control bibliográfico exclusivamente bibliotecario con normativa propia. Los nuevos recursos de información son organizados en gran parte por organizaciones que están al margen de las bibliotecas, lo que evidencia una necesidad de replanteamiento de las formas tradicionales de tratamiento documental.

El gran desarrollo tecnológico producido durante los últimos años ha propiciado la necesidad de actualización en las herramientas de control bibliográfico, que se apoyan ahora en nuevos planteamientos conceptuales. Es el caso, por ejemplo, del código RDA (Resource Description and Access), basado en los modelos conceptuales FRBR (Functional Requirements for Bibliographic Records) y FRAD (Functional Requirements for Authority Data) ${ }^{7}$.

\subsection{Análisis documental del cartel cinematográfico}

Como ya se ha comentado, en 1971 se publica la primera edición de las ISBD, de aplicación exclusiva para monografías. A partir de varias revisiones, nacen en 1977 las ISBD (G) de carácter general y que incluyen la descripción normalizada para todo tipo de materiales. Basándose en la estructura de las ISBD (G) se llevan a cabo múltiples normas que para la normalización de materiales concretos: ISBD (CM) para material cartográfico, las ISBD (PM) para música impresa, las ISBD (S) para publicaciones seriadas, las ISBD (A) para publicaciones monográficas antiguas, las ISBD (CF) para archivos de datos legibles por ordenador y las ISBD (NBM) para material no librario.

Hasta el año 2007 convivieron los ocho tipos de normas ISBD mencionadas, pero las ambigüedades existentes entre ellas llevaron a la necesidad de crear un grupo de revisión para unificar criterios. En 2003, se formó el Grupo de Revisión ISBD y el resultado fue la ISBD consolidada. La Biblioteca Nacional (2013), resume los avances que proporciona la nueva versión consolidada de las normas:

La ISBD consolidada proporciona una mayor armonización entre las estipulaciones de catalogación de los diferentes tipos de recursos y ofrece mayor facilidad de actualización de las estipulaciones. La

\footnotetext{
${ }^{7}$ Modelo basado en FRBR y dedicado a los registros exclusivamente de autoridad.
} 
unificación también ha posibilitado la actualización en cuanto a la obligatoriedad de un elemento de información, consiguiendo una mayor adaptación a los requisitos de información establecidos en FRBR.

Las ISBD han servido de base para desarrollar diferentes normas de aplicación nacional: en el caso español, las normas adaptadas son las Reglas de Catalogación y en el ámbito anglosajón, las Anglo-American Cataloguing Rules (AACR).

Las Reglas de Catalogación son una iniciativa de la Biblioteca Nacional que completan y mejoran algunos aspectos de la norma ISBD consolidada. Su organización se articula en torno a 17 capítulos que tratan desde la descripción bibliográfica general hasta las formas de encabezamiento, títulos uniformes y referencias de los asientos bibliográficos, pasando por el tratamiento documental de los diferentes materiales.

El tratamiento del cartel cinematográfico, atiende a la normativa reflejada en el capítulo 5 de las Reglas de Catalogación, que hace referencia a la descripción de los materiales gráficos.

\subsection{Tratamiento documental del cartel de cine en filmotecas y bibliotecas}

Al comenzar a trabajar en el diseño de un modelo documental para la descripción de la forma y del contenido del cartel cinematográfico, la primera medida que se tomó fue hacer una revisión de los trabajos que se estaban realizando en bibliotecas y filmotecas de todo el mundo.

El planteamiento desde el principio era ambicioso y prácticamente inabarcable por lo que, para encontrar una representación fiable y razonable de centros de documentación que se ocupasen del patrimonio audiovisual, se acudió a la lista de socios de la Federación Internacional de Archivos Fílmicos (FIAF). En septiembre de 2011, dicha organización contaba con 126 centros afiliados que son los que han servido de base para diseñar un modelo de tratamiento ajustado a los carteles de cine.

De las 126 instituciones asociadas a la FIAF, 75 no publica ningún dato relativo a la conservación de carteles entre sus fondos (59\%), frente a las 31 organizaciones que sí que lo reseñan (25\%). Hay 20 instituciones que, por las informaciones que aparecen en sus páginas web, no conservan carteles de cine, esto es el $16 \%$ del total de miembros de la FIAF (v. gráfico 1). 
Gráfico 1. Conservación de carteles en las instituciones asociadas a la FIAF.

Fuente: elaboración propia.



De entre los 31 centros que sí muestran los datos de carteles conservados en sus páginas web, cabe destacar la práctica de descripción de las siguientes filmotecas: Cineteca del Comune di Bologna (Italia), Fondation Jérôme Seydoux-Pathé (Francia), Institut Jean Vigo (Francia), Greek Film Archive (Grecia), la Filmoteca de Valencia (España) y la Filmoteca Española.

Resulta interesante para el diseño del modelo de tratamiento documental, las prácticas de descripción de carteles de la Cineteca del Comune di Bologna (Italia) y de los centros españoles Filmoteca Española y Filmoteca de Valencia.

Por su importancia, se han añadido tres casos más de bibliotecas no asociadas a la FIAF, cuyas prácticas descriptivas resultan de interés para el estudio que se aborda:

- Biblioteca Nacional de España.

- Margaret Herrick Library ${ }^{8}$ (EEUU).

- Prints and Photographs Division (Library of Congress, EEUU).

Se analizarán en primer lugar los centros de documentación internacionales, para después estudiar los casos de la Biblioteca Nacional, la Filmoteca Valenciana y, por último y con más detalle, el caso de la Filmoteca Española, centro principal de conservación y tratamiento de los carteles cinematográficos que se conservan en España.

\subsubsection{Prints and Photographs Division (Library of Congress)}

${ }^{8}$ Se trata de la biblioteca de The Academy of Motion Pictures Arts ans Sciences, más conocida como "la Academia de los Oscars". 
La Library of Congress de Washington (EEUU), tiene como objetivos primordiales apoyar al Congreso de los Estados Unidos en el cumplimiento de sus deberes constitucionales y promover el avance del conocimiento y la creatividad en beneficio del pueblo estadounidense.

Para cumplir con estos objetivos, la Biblioteca está estructurada en diferentes divisiones que se ocupan de las diferentes parcelas del conocimiento y del tratamiento documental de los distintos materiales que custodia. Del tratamiento de carteles se ocupa la Prints and Photographs Division, encargada de la gestión de grabados y fotografías que, como apunta Natanson (2001), ayudaron a formar la historia y la cultura de los Estado Unidos de América.

La Prints and Photographs Division cuenta entre sus fondos con: documentales y fotografías artísticas, grabados, dibujos animados y otros dibujos, carteles, documentación de la arquitectura, diseño e ingeniería, artes gráficas, partituras, materiales efímeros como semillas y tabaco, etiquetas de medicamentos patentados.

Los carteles están distribuidos en diversas colecciones de la Biblioteca: Artist Posters (85.000 carteles), Performing Arts Posters (2.100 carteles), Spanish Civil War Posters (120 carteles), World War I Posters (1.900 carteles), WPA Posters (2.000) y Yanker Poster Collection (3.000 carteles).

Los carteles de cine que custodia la Library of Congress se encuentran incluidos, por lo general, en la colección Performing Arts Posters (Carteles de Artes Escénicas), aunque pueden encontrarse también algunas imágenes de carteles en otras colecciones como Miscellaneous Items in High Demand (Colección de Ítems con Gran Demanda) o la Lester Glassner Collection of Movie Posters ${ }^{9}$ (Colección de Carteles de Cine de Lester Glassner).

La norma utilizada por la Library of Congress para la catalogación de los materiales, en este caso de los carteles de cine, es la angloamericana AACR2: realiza una descripción formal del documento y le asigna los correspondientes puntos de acceso añadiendo además un breve resumen de contenido a la ficha incluido en el campo Summary. En el campo notas (Notes) se incluyen datos relativos al cartel que no tienen cabida en los campos de descripción formal: copyright, historial de exhibiciones del cartel, etc.

\subsubsection{Margaret Herrick Library (EEUU)}

La Margaret Herrick Library es la biblioteca de The Academy of Motion Picture Arts and Sciences, más conocida como la "Academia de los Oscars de Hollywood". Las colecciones que alberga esta institución están compuestas por documentos dedicados a la historia del cine y a su industria. Se fundó en 1928, un

${ }^{9}$ Colección de carteles de cine recopilados por Lester Glassner y donada a la Library of Congress en 2001. La colección posee aproximadamente 500 carteles de cine de las décadas de los años veinte, treinta, cuarenta y cincuenta. 
año después de la creación de la Academia, y en 1991 trasladó su ubicación a Beverly Hills (Los Angeles, California).

Los carteles cinematográficos que conserva la Biblioteca están recogidos en la colección Graphic Arts Collection que incluye más de 42.000 ejemplares de carteles publicitarios de películas de los orígenes del cine, de producciones de Hollywood y algunos ejemplos de producciones independientes y extranjeras.

La descripción que hace la Biblioteca de los carteles cinematográficos en su catálogo (basada en las normas AACR2) es una de las más completas que se han encontrado para la realización de este estudio. Combina datos de la película propiamente dicha con datos propios del cartel y realiza una descripción muy interesante de la imagen y el texto en su apartado de notas.

Los campos que emplea para la descripción de carteles de cine son:

- Title: en el que incluye en formato AACR2, el área de título y mención de responsabilidad (título de la película y director/es). Detrás del título incluye la especificación de tipo de material "[poster]".

- Linked Resources: imagen del cartel de cine que se describe.

- Other Author(s): puntos de acceso secundario a autoridades propias de la película (no del cartel).

- Subjects: referencia a materias.

- Form/Genre Type: género o géneros cinematográficos a los que pertenece la película.

- Publisher: datos de publicación del cartel.

- Los Ángeles Release: datos relativos al estreno de la película en la ciudad de Los Ángeles (California, EEUU). Incluye el nombre de la distribuidora y el año del estreno.

- Description: área de publicación (reseña el país al que pertenece el cartel) y área de descripción física, presentada en formato AACR2.

- Notes: descripción detallada de la imagen y el texto que componen el cartel.

- Collection: sección o subcolección a la que pertenece el cartel, dentro de la colección general Graphic Arts Collection.

- Additional Format: formato de la imagen digitalizada del cartel.

- Reproduction note: notas relativas a la imagen digitalizada (reproducción del cartel original).

\subsubsection{Cineteca di Bologna (Italia)}

La Cineteca di Bologna se fundó en 1963 por la Comissione Cinema de Italia bajo la premisa: "si el pasado está vivo, entonces también tiene un futuro" (Fondazione Cineteca di Bologna, 2013). Casi cincuenta años después, en 2012, la Cineteca pasó a convertirse en una fundación para mejorar su gestión y el aprovechamiento de sus recursos. La misión de la Fondazione Cineteca di Bologna es ser un lugar para la conservación de los archivos y la restauración del cine y sus 
materiales promocionales. Igualmente, se erige como una institución difusora del patrimonio que contribuye a la investigación y a la publicación de temas relacionados con el cine.

Los carteles de cine se integran dentro de la sección Non-Film Archive, que hace referencia a la conservación de documentos de creación y distribución del producto cinematográfico. El fondo del Archivo Gráfico (subsección del Non-Film Archive) cuenta con más de 200.000 documentos, de los cuales 40.000 son carteles, programas de mano y carteleras.

Cabe destacar el trabajo realizado por la Cineteca di Bologna en el desarrollo de unas directrices que adaptan la descripción de la norma ISBD al caso concreto de los materiales gráficos cinematográficos: la Linee guida per catalogazione del corredo grafico e promozionale di cinema (Cineteca di Bologna, 2011).

Estas directrices son el resultado del trabajo con cerca de 24.000 documentos gráficos de los fondos de la Cineteca, que ha permitido adaptar y mejorar la norma ISBD para ajustar su descripción a cada tipo de material gráfico.

\subsubsection{Biblioteca Nacional de España}

La Biblioteca Nacional de España fue fundada en el año 1711 por el rey Felipe V y abrió sus puertas como Real Biblioteca Pública en 1712. En 1836, La Biblioteca pasó de depender de la corona a depender del Ministerio de la Gobernación, transformándose entonces en Biblioteca Nacional.

El objetivo de la Biblioteca es recibir y conservar ejemplares de todos los libros que se publican en España. Además, cuenta con una gran variedad de colecciones de estampas, dibujos, partituras y carteles entre otros.

La colección de carteles de la Biblioteca Nacional (2013), se subdivide a su vez en tres colecciones: los carteles publicitarios, los carteles de la República y la Guerra Civil (con depósito en el Servicio de Dibujos y Grabados) y los carteles posteriores a 1957 y que han entrado a formar parte de la Biblioteca a partir de la Ley de Depósito Legal:

- Colección de carteles publicitarios: se comenzó a formar en 1867 gracias al bibliotecario de la institución Genaro Alenda y Mira, que creó la Sección de Papeles Varios. A través de la compra, donación y depósito, Alenda consiguió reunir un sustancioso número de carteles entre $1870 \mathrm{y}$ 1889. Tras sucesivos traslados, los carteles llegaron en mal estado de conservación al Servicio de Dibujos y Grabados de la Biblioteca donde se restauraron y se dieron a conocer en 2002 en la exposición Memoria de la seducción: carteles publicitarios del siglo XIX en la Biblioteca Nacional.

- Colección de carteles de la República y la Guerra Civil: esta colección cuenta con más de 500 carteles y se comenzó a formar a partir de 1982 por una compra a un particular realizada por el Centro Nacional del 
Tesoro Documental y Bibliográfico del Ministerio de Cultura para la Biblioteca Nacional y se ha ido incrementando con los años.

- Colección de carteles posteriores a la Ley de Depósito Legal de 1957: a partir de la promulgación de la Ley de Depósito Legal de 1957, la Biblioteca Nacional comienza a recibir multitud de carteles (hoy día cerca del millón de unidades), que se catalogan y conservan en la sede de la Biblioteca en Alcalá de Henares. Entre sus fondos se pueden encontrar algunos ejemplos de carteles cinematográficos.

Las normas de descripción que utiliza para el análisis de los carteles, son las Reglas de Catalogación españolas atendiendo a las directrices de su capítulo 5 (relativo a la descripción de materiales gráficos). Todos los campos utilizados para la descripción hacen referencia a las características formales del cartel salvo el campo repetible Nota general, que se emplea para detallar otras informaciones relacionadas con el contenido del cartel como es la información que resulta interesante de la película o la descripción del texto que aparece impreso en el propio cartel.

\subsubsection{Filmoteca de la Generalitat Valenciana}

El Archivo Gráfico de la Filmoteca valenciana (inscrita dentro del Instituto Valenciano del Audiovisual y de la Cinematografía - IVAC) es uno de los pocos casos de instituciones públicas españolas que reseñan entre sus fondos carteles de cine. Aunque en el catálogo del IVAC no aparecen catalogados los fondos cartelísticos de la institución, en la página web si se describen algunas prácticas que lleva a cabo la Filmoteca para la conservación de los carteles de cine.

El Archivo Gráfico cuenta con alrededor de 35.000 documentos procedentes de las actividades del IVAC y, en menor medida, de donaciones, depósitos y compras. Entre los documentos gráficos que conforman el fondo del archivo, pueden encontrarse carteles, fotografías, programas de mano, postales y diapositivas.

La propia Filmoteca valenciana, en su publicación La Imagen rescatada: recuperación, conservación y restauración del patrimonio cinematográfico (1991, p. 123), presenta un ejemplo de catalogación del cartel de la película Castigo de Dios en el que se observan los campos de la descripción propia del cartel combinados con datos propios de la película: Director, Productora, Género y Componentes/Intérpretes. Llama la atención el detalle de la firma "Toniko" que aparece reflejada en el campo Autor de la descripción del cartel. 
Figura 2. Descripción del cartel Castigo de Dios (1925).

Fuente: Filmoteca de la Generalitat Valenciana, 1991.

A.

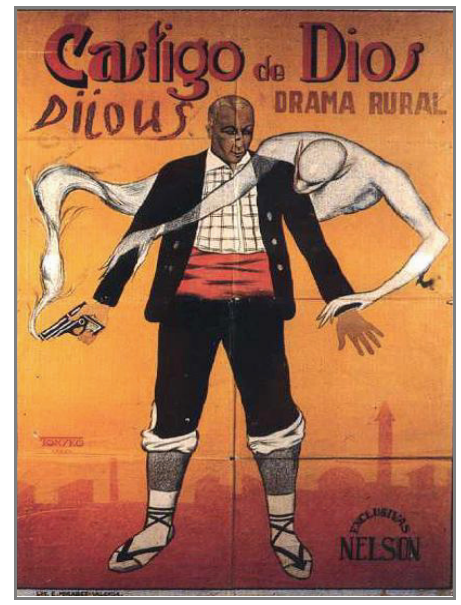

B.

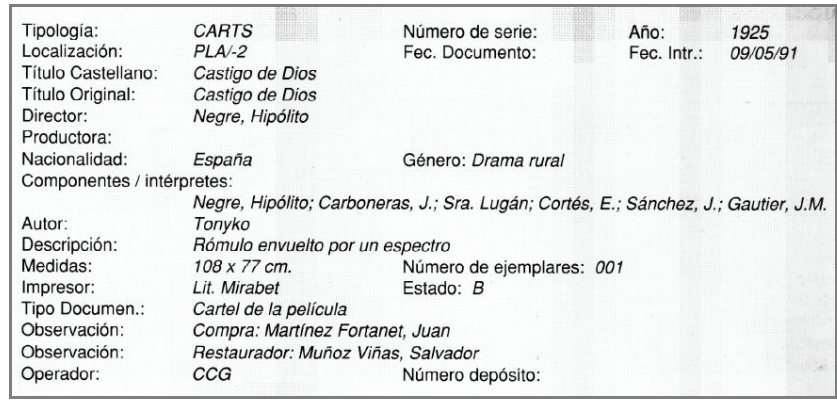

Figura 2. A. Cartel de la película Castigo de Dios (1925); B. Descripción del cartel según la Filmoteca de la Generalitat Valenciana.

\subsubsection{El Archivo Gráfico de Filmoteca Española}

El 22 de marzo de 1953, el Boletín Oficial del Estado publica un decreto de 13 de febrero por el que se establece la creación de la Filmoteca Nacional, que años más tarde pasaría a llamarse Filmoteca Española. Esta institución nace con el objetivo de preservar el patrimonio cinematográfico y así lo justifica en el preámbulo del citado decreto de 13 de febrero (22 de marzo, 1953):

La importancia adquirida por la cinematografía entre las diversas manifestaciones de la vida moderna y especialmente como elemento docente y cultural, obliga a otorgarla un trato análogo al que se concede a otras destacadas manifestaciones intelectuales, para evitar que desaparezcan sus ejemplares una vez cumplido el primer objetivo a que se les destina. Esta consideración aconseja procurar que se conserven aquellas obras cinematográficas que, en el presente o en el futuro puedan tener algún valor artístico, técnico, documental, social o histórico, estableciendo para ello un centro que contribuya eficazmente a dicho fin y al mismo tiempo haga posible el estudio del cinematógrafo en sus diversas etapas y la consulta de aquellos ejemplares inactuales, por los sectores más directamente interesados en sus problemas. (p. 1499). 
En el mismo decreto de 13 de febrero, en su artículo $2^{\circ}$, define la misión de la Filmoteca y contempla la custodia de materiales cinematográficos diferente de las películas: "Tendrá como misión la Filmoteca Nacional la de crear un archivo de películas y de documentación cinematográfica procurando su mejor conservación y haciendo posible que el material archivado se utilice solo con fines culturales."

En este sentido, la misión del Archivo Gráfico es custodiar y dar tratamiento a los materiales gráficos relacionados con los procesos de producción y distribución de las películas, prestando además su colaboración a los diferentes departamentos de la Filmoteca y al público externo que reclame sus servicios.

Según los datos ofrecidos en la obra Filmoteca Española: cincuenta años de historia (1953-2003) (Filmoteca Española, 2005, pp. 158-160), el Archivo Gráfico cuenta entre sus fondos con: 500.000 fotografías, 25.000 negativos, 8.000 diapositivas, 5.000 placas de cristal, más de 40.000 carteles, 25.000 carteleras, 6.000 programas de mano, 10.000 fotocromos, 75.000 guías de prensa.

Durante la primera década de este siglo, se tomaron medidas para mejorar la organización de los fondos del Archivo Gráfico, con especial cuidado al material publicitario estrella: los carteles de cine.

Sin embargo, los cambios producidos en la Administración durante los últimos años, han propiciado una serie de recortes de personal y de recursos que han derivado una paralización casi total de las tareas de catalogación del fondo de carteles de la Filmoteca Española.

Hasta agosto 2007, los carteles de cine se registraban a su entrada en el archivo en una base de datos diseñada en Microsoft Office Access que contemplaba los siguientes campos: $\mathrm{n}^{\circ}$ de entrada, título, director, signatura, $\mathrm{n}^{\circ}$ de ejemplares, autor del cartel y observaciones. Una vez registrados en la base de datos pasaban a ser ordenados dentro de los planeros que tienen destinados para la organización y preservación de los carteles de cine.

En agosto de 2007, Filmoteca Española se embarcó en el proyecto de integración de sus fondos en la base de datos FLORA, una iniciativa francesa tomada y adaptada por el departamento de informática del Ministerio de Cultura español para la descripción y digitalización del patrimonio audiovisual de España.

El proyecto no consiguió salir adelante y, al poco tiempo, se instaló el sistema de gestión integral de bibliotecas Absys.net de la empresa Baratz. Este sistema da soporte a la Biblioteca y al Archivo Gráfico y permite la descripción de carteles en formato MARC según las normas ISBD. El objetivo es que en un futuro puedan integrarse las imágenes de los carteles a los registros de descripción aunque de momento hay que conformarse con la descripción formal del cartel, como aparece en el ejemplo de la figura 3. 
Figura 3. Descripción del cartel de la película El difunto es un vivo (1941). Fuente: Catálogo de la Biblioteca de la Filmoteca Española, 2013.

\begin{tabular}{|ll|}
\hline $\begin{array}{l}\text { Autor: } \\
\text { Otros responsables: }\end{array}$ & $\begin{array}{l}\text { José María } \\
\text { - Iquino, Ignacio F. (1910-1994)-director } \\
\text { - Cifesa-distribución }\end{array}$ \\
Título Uniforme: & El difunto es un vivo. 1941 \\
Título: & El difunto es un vivo [Material Gráfico] / José María \\
Publicación: & Valencia : Lit. Mirabet, [1941] \\
Descripción: & 1 cartel : Color, Litografía ; 99 x 67,3 cm. \\
Signatura: & - Archivo Gráfico. Cuarta Planta, 55/15.1 \\
& - Archivo Gráfico. Cuarta Planta, 55/15.2 \\
\hline
\end{tabular}

\section{MODELO DE TRATAMIENTO DOCUMENTAL DEL CARTEL DE CINE}

Las diferentes experiencias practicadas en bibliotecas y filmotecas de todo el mundo, ponen de relieve las prácticas descriptivas que se están realizando sobre los carteles cinematográficos en centros de tan reconocido prestigio como la Library of Congress, la Margaret Herrick Library o la propia Biblioteca Nacional española.

El estudio de las prácticas desarrolladas en estos centros, ha servido de orientación y reflexión para el diseño de un modelo documental que describa de forma precisa cada uno de los elementos que componen el cartel cinematográfico.

En general, como se ha visto, las fichas descriptivas de las bibliotecas y filmotecas centran su atención a los aspectos formales del cartel, integrando datos de contenido que tienen que ver directamente con el film que publicita, pero no con la propia composición del cartel de cine. La carencia en el análisis se manifiesta, por lo tanto, en la descripción del contenido del cartel más que en el análisis de sus características formales.

Para realizar un análisis documental preciso del cartel cinematográfico, se aborda el diseño del modelo de tratamiento desde dos perspectivas: el análisis formal y el análisis de contenido. Esta doble perspectiva es tratada por Ruiz Pérez (1992) en la definición que ofrece de análisis documental:

El conjunto de operaciones a realizar para poder representar el contenido del documento de forma distinta a éste y ser fácilmente consultado y localizado en un momento posterior. El análisis documental se estructura en dos niveles: nivel externo o formal y nivel interno o de contenido. (p. 21).

El análisis formal del cartel cinematográfico del modelo diseñado para esta investigación, se centra en las directrices marcadas por las Reglas de Catalogación españolas de 1999 que, como ya se ha comentado, están basadas en la norma ISBD 
consolidada. Además, se atenderá a algunos aspectos importantes para la descripción destacados en la Linee guida per catalogazione del corredo grafico e promozionale di cinema de la Cineteca di Bologna (2011), norma desarrollada a partir de la ISBD con modificaciones realizadas a partir del estudio de un fondo de 24.000 carteles.

Por otro lado, el análisis de contenido del modelo se centra en la descripción de los elementos que componen la estructura semiótica mixta del cartel, es decir, el análisis de la imagen, del texto y de los logotipos.

El cartel cinematográfico, aunque es un documento autónomo con unas características propias que se definen a través del análisis formal y de contenido, está estrechamente vinculado a la película que publicita. Es por ello, que un tercer apartado del modelo documental, contempla una ficha descriptiva con los elementos más representativos de la película.

\subsection{Análisis formal del cartel de cine}

La organización de la descripción formal del cartel de cine español de posguerra está basada en la descripción de materiales gráficos definida en el capítulo 5 de las Reglas de Catalogación (2010, p. 157), que incluye "los materiales gráficos, bidimensionales, tales como estampas, dibujos técnicos, fotografías, carteles, láminas, etc., ya sean originales o reproducciones."

La descripción se organiza a partir de siete de las ocho áreas que establece la norma para la descripción bibliográfica general. El Área 3, correspondiente a los datos específicos de la clase de documento, no aparece contemplada para la descripción de los materiales gráficos. Las siete áreas a las que se hace referencia son: Área 1: Título y Mención de Responsabilidad; Área 2: Edición ${ }^{10}$; Área 4: Publicación; Área 5: Descripción Física; Área 6: Serie ${ }^{11}$; Área 7: Notas; y Área 8: Número Normalizado y Condiciones de Adquisición.

Clausó (2001, p. 30) diferencia para el análisis formal de los documentos dos operaciones diferentes: la descripción bibliográfica, que se ocupa de la redacción del asiento bibliográfico exclusivamente y la catalogación, que se encarga de la ordenación en los catálogos a través de los encabezamientos y de las fichas secundarias. Es por ello que, además de las diferentes áreas de descripción, la ficha cuenta con otros elementos que definen los puntos de acceso al documento:

${ }^{10}$ La edición no es un dato característico del cartel por lo que no se hará constar ni en la descripción general ni en la ficha ISBD a no ser que aparezca impresa en el cartel: "se hará una mención de edición indicando aquella a la que pertenece el documento o los cambios significativos introducidos con respecto a una anterior, siempre que el documento lo haga constar formalmente. La mención relativa a una primera edición podrá omitirse" (Reglas de Catalogación, 2010, apdo. 1.2.3. A, p. 32).

${ }^{11}$ No es habitual la utilización del Área 6 en la descripción de carteles de cine por lo que no se profundizará en su aplicación en los siguientes apartados. 
- El encabezamiento: se toma como encabezamiento el título del cartel.

- Registro de fichas secundarias: entradas secundarias del autor o autores del cartel y entrada por título uniforme si lo tuviese.

En el modelo de tratamiento del cartel de cine se establecen tres partes para el análisis formal:

1. Descripción general, a través de los campos: Título; Título uniforme (en caso de tenerlo); Autor; Lugar; Publicación; Año; Imprenta: Lugar de Impresión y Empresa Gráfica; Descripción Física: Hojas, Dimensiones, Técnica, Soporte, Posición, Color, Restaurado; Estado de conservación: Valoración; Observaciones; y Depósito Legal.

2. Notas (análisis formal): las notas relativas al análisis formal que no tienen cabida en los campos de la descripción general.

3. ISBD: los datos aportados en la descripción general se presentan en formato ISBD con la asignación de los puntos de acceso de encabezamiento y secundarias de autor y título uniforme.

A continuación se describirán las áreas relevantes para la descripción del cartel de cine y su aplicación en base a las Reglas de Catalogación (2010), incluyendo las apreciaciones particulares que se han tomado de acuerdo con la Linee guida per catalogazione del corredo grafico e promozionale di cinema desarrollada por la Cineteca di Bologna (2011).

\subsection{1. Área 1: Título y mención de responsabilidad}

El primer elemento del área es el título que conforma además el encabezamiento o punto de acceso al documento. El título que se toma es el que aparece impreso en el cartel y, en caso de no coincidir con el título de la película que se publicita, se sacará este último en secundaria de título uniforme.

El título se transcribirá en mayúsculas al tomarse como encabezamiento y respetando la acentuación ortográfica, es decir, acentuando las palabras mayúsculas aunque aparezcan sin acentuar en la fuente. Será en el campo Resumen, donde se transcribirá el título tal cual viene en el cartel, respetando su tipografía, las palabras no acentuadas, etc.

Por su parte, la mención de responsabilidad hace referencia al autor entendido como el responsable intelectual del cartel, ya sea un cartelista individual, un grupo de cartelistas o un estudio de publicidad. Si no se reseña autor, la obra se considerará anónima.

Atendiendo a las Reglas de Catalogación (2010, p. 22, apdo. 1.1.7. D. a.), las menciones de responsabilidad se transcribirán tal cual aparecen en la fuente original es decir, la firma que aparece en el cartel. El caso habitual es que la citada firma no represente el nombre completo del autor, en cuyo caso se reseñará en el Área 7, empleando la nota: "Nombre completo del autor:" (Reglas de catalogación, 2010, p. 58, apdo. 1.7.4. A. a.). Por último, se sacará un punto de acceso secundario con el nombre completo del autor del cartel. 
Para los casos en los en que el autor firme bajo seudónimo, se reseñará éste en la mención de responsabilidad y, en secundaria, el nombre original del autor. En notas, se aplicará la misma fórmula que para el resto de menciones, la fórmula "Nombre completo del autor:" seguida del nombre, apellidos y seudónimo entrecomillado.

Por último, se reseñará la designación general de tipo de documento después del título del cartel. Este elemento cobra interés en catálogos formados por más de un tipo de material para diferenciar a qué clase pertenece el documento que se describe. Para el caso de los carteles, lo habitual es que aparezca entre corchetes la mención "[Material Gráfico]".

\subsection{2. Área 4: Publicación}

Como pone de manifiesto la Linee guida per catalogazione del corredo grafico e promozionale di cinema (Cineteca di Bologna, 2011), el fabricante o impresor del cartel y el distribuidor de la película tienen un papel activo en la creación de la publicidad anunciadora de un film. Es por ello, que ambos deben aparecer representados en la descripción del documento. De acuerdo con la citada guía de la Cineteca di Bologna y con las Reglas de Catalogación (2010, p. 172, apdo. 5.4.4. D.), el formato de representación será: "lugar: editor, fecha (lugar de impresión: imprenta)".

La primera parte de la descripción hace referencia al editor, que será el distribuidor y/o productor de la película. El orden para la elección de editor, por lo tanto, es el mencionado: primero el distribuidor y, en caso de no tener, el productor siempre que haga las funciones de distribución del film.

El lugar de publicación será la población donde estén localizadas las oficinas centrales nacionales de la distribuidora o, en su caso, de la productora. Si los datos provienen de fuentes externas, se reseñarán ente corchetes y, en caso de no obtener de ninguna fuente los datos de publicación del editor, se señalará con la formula [s.l. : s.n.].

La fecha de publicación, hace referencia al cartel y no al film. Sin embargo, no es habitual encontrar carteles con la fecha impresa -al menos hasta la aparición del Depósito Legal en 1957-, por lo que hay que aproximar su edición a través de las fechas propias de la película. El orden de asignación de fechas será el siguiente: fecha impresa en el cartel, fecha del Depósito Legal (precedida de las siglas D. L.), fecha de estreno de la película, fecha de censura de la película y fecha de producción de la película. Cuando el dato de fecha se extraiga de una fuente diferente al cartel, se representará entre corchetes con la sigla ca. (circa) delante: [ca. ].

La segunda parte del área de publicación corresponde a los datos de la imprenta productora del cartel. Los datos que se recogen son lugar y nombre de la imprenta entre paréntesis y separados entre sí por dos puntos: "(lugar: imprenta)". 


\subsection{3. Área 5: Descripción física}

Las Reglas de Catalogación (2010, pp. 46-50, apdo. 1.5), establecen tres secciones para la descripción física de un material gráfico:

- Extensión y designación de material: se trata de la indicación del tipo de material y del número de unidades o extensión del documento que se describe: "1 cartel (2 hojas)".

- Mención de otras características físicas: hace referencia a la técnica empleada para la creación de la obra. Para los carteles de cine español del periodo de posguerra, por ejemplo, la técnica empleada es la "litografía", que aparecerá seguida y separada por coma de la sigla "col.", que indica que los carteles están impresos a color: "litografía, col.".

- Dimensiones: las dimensiones se presentaran en centímetros bajo la forma alto $x$ ancho. Las medidas corresponden a las del cartel completo (para los casos en los que estén compuestos por más de una hoja).

Aparte de las tres secciones descritas, en el modelo de tratamiento diseñado para esta investigación, se observan tres campos añadidos que registran datos propios de la descripción física:

- Soporte: refleja el soporte original del cartel. En el caso de estar restaurado sobre otro material, se destacará en notas.

- Posición: hace referencia a la orientación vertical u horizontal del cartel.

- Restaurado: indicación sí o no, según el caso.

En la descripción general del modelo de tratamiento, se observa el apartado Estado de conservación separado y al mismo nivel que la Descripción fisica. El objetivo es diferenciar y destacar su contenido, pero se describe en este punto al hacer alusión al estado físico del cartel y al guardar relación, en muchos casos, con el campo Restaurado. Los dos campos que registran la información del estado de conservación son:

- Valoración: bajo la clasificación excelente, bueno, regular y malo.

- Observaciones: solamente se refleja este campo si es necesario referenciar alguna información relativa a la valoración realizada.

\subsection{4. Área 7: Notas}

Según parece indicado en las Reglas de Catalogación (2010, p. 56, apdo. 1.7.), por su naturaleza, las notas tienen por objeto "suministrar información que no haya podido ser expresada en las restantes áreas y esté directamente o indirectamente relacionada con el documento que se describe". Hay que recordar que las notas han de aparecer siempre representadas por orden del área a la que hacen referencia. 


\subsection{5. Área 8: Número Normalizado y Condiciones de Adquisición}

En la descripción bibliográfica general de las Reglas de Catalogación (2010, p. 61, apdo. 1.8.3.a), se establece que en el primer elemento del Área 8, se indicará el número normalizado que corresponda según el tipo de documento.

En el caso del cartel cinematográfico, el número normalizado es el depósito legal, que entra en vigor en España por Decreto de 23 de diciembre de 1957 (20 de enero de 1958). El objetivo de dicho decreto, es regular algunas medidas que se venían tomando desde $1711^{12}$ para cumplir con el deber de preservación patrimonial por parte del Estado.

La última revisión del depósito legal español se realizó en 2011 con la Ley 23/2011, de 29 de julio (30 de julio, 2011). Su objetivo principal aparece expuesto en el primer artículo:

Regular el depósito legal, que se configura como la institución jurídica que permite a la Administración General del Estado y a las Comunidades Autónomas recoger ejemplares de las publicaciones de todo tipo reproducidas en cualquier clase de soporte y destinadas por cualquier procedimiento a su distribución o comunicación pública, sea ésta gratuita u onerosa, con la finalidad de cumplir con el deber de preservar el patrimonio bibliográfico, sonoro, visual, audiovisual y digital de las culturas de España en cada momento histórico, y permitir el acceso al mismo con fines culturales, de investigación o información, y de reedición de obras, de conformidad con lo dispuesto en esta ley y en la legislación sobre propiedad intelectual. (p. 86719).

En el artículo $4^{\circ}$, aparecen detallados todos los tipos de documentos que quedan sujetos a depósito legal obligatorio: el cartel se inscribe en el apartado 3.h. (p. 86721) "Carteles anunciadores y publicitarios".

El número de depósito legal aparece impreso en los carteles de cine a partir de 1957. Los impresos en fechas anteriores, no cuentan con ningún número normalizado que los identifique $y$, por lo tanto, no se refleja este dato a la hora de ser descritos formalmente.

12 En 1711 se inaugura la Biblioteca Nacional de España que, como ya se ha comentado, nace con el objetivo de recibir y conservar ejemplares de todos los libros que se publican en España. Sin embargo, la figura del depósito legal nace casi un siglo antes, en 1616, cuando Felipe III concede a la Real Biblioteca de El Escorial el privilegio de recibir un ejemplar de todos los libros que se imprimiesen. 


\subsection{Análisis de contenido del cartel de cine}

La segunda fase del análisis documental es el análisis de contenido, que se realiza en el caso del cartel de cine a través de dos operaciones clave: la indización y el resumen.

La indización es en palabras de Fox (2005, p. 25): "la operación que permitirá representar al documento analizado bajo diversos términos que tendrán la característica de ser unívocos. Esos términos serán seleccionados de lenguajes documentales o lenguajes de indización (libres o controlados y de estructura asociativa o sintáctica)."

Por otro lado, es importante destacar la importancia del resumen en el análisis documental de contenido. Valle Gastaminza (1999, p. 126) ofrece una serie de recomendaciones para la realización de resúmenes de fotografías: "debe ser muy descriptivo y en su redacción debemos tener en cuenta que tenemos que elegir qué incluimos, de tal manera que no aparezcan elementos anecdóticos en detrimento de otros más trascendentes". Por su calidad de documento gráfico, el caso de la fotografía se aproxima más al cartel cinematográfico de lo que puede acercarse un documento puramente textual.

En definitiva, el resumen para el cartel de cine deberá ser un resumen descriptivo, en lenguaje natural, con el que se exprese de forma breve el contenido esencial de los elementos que lo componen, esto es: el texto, la imagen y los logotipos.

Para elaborar un modelo de análisis de contenido completo del cartel cinematográfico, se combinan las operaciones de resumen e indización con el análisis de los ya estudiados constituyentes del discurso publicitario -definidos por Adam y Bonhomme (2000, pp. 73-111) como los componentes de la estructura semiótica mixta del anuncio publicitario- y se establecen cinco partes fundamentales para el análisis:

1. Análisis textual: análisis de los elementos textuales del cartel centrado en la transcripción de las personas y empresas que aparecen textualmente representadas y en la descripción del eslogan en caso de tenerlo.

2. Análisis visual: representación de los temas visuales a través de los tipos de descriptores: geográficos, onomásticos y temáticos.

3. Análisis de logotipos: trascripción y representación visual de los logotipos.

4. Resumen: descripción exhaustiva de todos los elementos que constituyen el cartel, esto es, de la imagen, del texto y de los logotipos.

5. Notas (análisis contenido): todas las notas relativas al análisis de contenido que no tienen cabida en los cuatro apartados anteriores. 


\subsubsection{Análisis textual}

Para la representación de los textos del cartel, se atiende a tres elementos: personas, empresas y eslogan.

1. Personas: incluye el registro de los nombres de las personas que aparecen textualmente representadas en el cartel. Se compone a su vez de dos subsecciones estructuradas en campos:

- Cartelista: representación del nombre del artista personal o colectivo $^{13}$ a través de dos campos:

- Firma del cartelista: transcripción de la firma del cartelista tal cual viene impresa en el cartel.

- Detalle de la firma: imagen de la firma del cartelista ampliada.

- Equipo técnico y artístico: recoge los nombres de las personas en su forma aceptada, con formato nombre y apellidos ${ }^{14}$ ordenados por orden aparición en el cartel:

- Director.

- Intérpretes.

- Profesionales y técnicos: detrás de cada nombre, conviene detallar entre paréntesis su responsabilidad en la película de acuerdo con la siguiente nomenclatura: Argumento, Decorados, Fotografia, Guión, Música, Productor y Supervisión.

- Transcripción del equipo técnico y artístico: transcripción de los nombres respetando el orden de representación en el cartel. La lectura se realizará de arriba abajo y de izquierda a derecha (desde el punto de vista del observador). Las preposiciones o frases que acompañen al nombre serán trasladadas a la transcripción tal cual aparecen en el cartel.

2. Empresas: representación de los nombres de las empresas que aparecen nombradas en el cartel ya sea textualmente o a través de un logotipo ${ }^{15}$ :

- Productora.

- Distribuidora.

- Estudio.

- Imprenta: nombre de la imprenta (sin la dirección postal) en que se imprimió el cartel siempre y cuando figure representado textualmente en él.

\footnotetext{
${ }^{13}$ En el caso de que la autoría corra a cargo de una empresa de publicidad, la transcripción se realizará en el apartado correspondiente a empresas.

${ }^{14}$ En un catálogo automatizado, lo normal sería mostrar los nombres en el formato Apellidos, Nombre puesto que serían recuperados de una tabla de autoridades.

15 Aunque los logotipos tienen su área propia de representación, las empresas que aparecen representadas con logos textuales o textuales-figurativos, también se destacan en esta sección de empresas.
} 
- Transcripción de las empresas: al igual que sucedía en el caso de la transcripción de las personas, se representan las empresas en el orden de aparición, separadas por punto y coma y acompañadas de las palabras que las acompañan en el texto original del cartel.

3. Eslogan: transcripción del eslogan o frase publicitaria en caso de aparecer en el cartel, y su clasificación o tipo:

- Eslogan.

- Tipo de eslogan: gancho (head-line) o frase de asiento (base-line).

\subsubsection{Análisis visual}

Aunque la descripción detallada de la imagen se realizará, como se verá más adelante, en la primera parte del Resumen, se considera necesario indizar el contenido visual del cartel a través de descriptores temáticos en lenguaje libre. Los tres tipos de descriptores empleados son los definidos para el análisis de la fotografía por Valle Gastaminza (1999, p. 128):

- Descriptores geográficos: para lugares o ámbito geográfico.

- Descriptores onomásticos: nombres propios de las personas que figuran en la imagen o imágenes del cartel.

- Descriptores temáticos: para objetos, acciones, actividades, situaciones o conceptos relacionados con la parte visual del cartel.

\subsubsection{Análisis de logotipos}

El logotipo es el elemento icónico-textual que representa la marca de una empresa. En el caso del cartel cinematográfico, los logotipos que habitualmente aparecen representados son los de la productora, la distribuidora, los estudios de rodaje y, en casos más concretos, los de la empresa publicitaria encargada de la elaboración del cartel. Para su descripción se utilizan dos campos:

- Nombre de la empresa: aparecerá representado en su forma completa y, en función de qué tipo de empresa sea, así aparecerá nombrado el campo: si es una empresa productora, se representará bajo la fórmula "Productora: nombre".

- Detalle del logotipo: imagen ampliada del logotipo que aparece en el cartel.

\subsubsection{Resumen}

El resumen constituye la descripción integradora de todos los elementos que componen el cartel de cine. Redactado en lenguaje libre, el resumen combina la descripción de imágenes con la transcripción literal de textos. El orden que se propone para la representación de los diferentes elementos es: primero la descripción de la imagen y, segundo, la transcripción y descripción de textos y logotipos. 


\section{Descripción de la imagen:}

- Descripción de la imagen principal del cartel en la que aparecen generalmente los actores centrales de la película (star system). En su descripción se detalla su nombre original y el del personaje que interpreta el actor o actriz.

- Para designar su localización en la composición, lo habitual es dividir el cartel en mitades o tercios, por ejemplo: mitad inferior derecha, tercio superior izquierdo, etc. La lectura de la imagen siempre se realiza en función del observador.

- Para designar los planos en los que aparecen representadas las personas, escenas u objetos se utiliza la clasificación: plano general, primer plano, plano medio y plano americano.

- Descripción de actores y actrices secundarias en los mismos términos que la descripción de los artistas principales.

- Descripción de las imágenes diegéticas: representación de las escenas de la película que aparecen en el cartel por orden de relevancia.

- Descripción del color o colores de fondo del cartel.

\section{Transcripción y descripción del texto y del logotipo:}

- Representación del título de la película, incluyendo una descripción de su composición visual. Hay que recordar que el título es el elemento textual más destacado del cartel y su representación suele ser más llamativa y original.

- Transcripción del reparto de artistas por orden de importancia y de aparición en el cartel y descripción tipográfica (tamaño, color de las letras, etc.).

- Transcripción del nombre del director y su descripción tipográfica.

- Transcripción de los nombres del resto de profesionales y técnicos, así como la descripción tipográfica de sus nombres.

- Transcripción del eslogan, en caso de tenerlo, y su descripción tipográfica.

- Transcripción de las empresas que aparecen en el cartel a través de la localización de sus logotipos.

- Descripción de los elementos del margen: nombre y localización de la empresa gráfica que se ocupa de la realización del cartel.

\subsubsection{Notas de contenido}

Al igual que sucedía con las notas relativas al análisis formal, el campo Notas (análisis de contenido) se contempla para registrar aquellos datos que no hayan podido ser añadidos a ningún otro campo y que sean de interés para la descripción del contenido del cartel. 


\subsection{Información complementaria: la ficha de la película}

Como ya se estudió al hablar del cartel de cine dentro del patrimonio cinematográfico, el cartel anunciador de una película está dotado de una serie de características que lo convierten en documento autónomo, pero pertenece a una realidad más amplia que está formada por todos los documentos que se generan en el proceso de producción y distribución de una película. Por lo tanto, el cartel está vinculado al film que publicita desde su génesis. Esta es la razón por la que es importante contribuir con los datos de la película a completar la información descrita del cartel.

Los datos que se aportan de la película se articulan en torno a dos secciones: la primera, dedicada a representar la Información de fechas de la película y, la segunda, dedicada a la ficha técnica o Ficha de la película.

1. Información de fechas: fecha de producción, fecha de censura y fecha de estreno.

2. Ficha de la película: título de la película, director, intérpretes, profesionales y técnicos, productora, distribuidora, estudios, nacionalidad, género, color, duración (min.), argumento y notas.

\subsection{Ejemplo de análisis documental de un cartel cinematográfico}




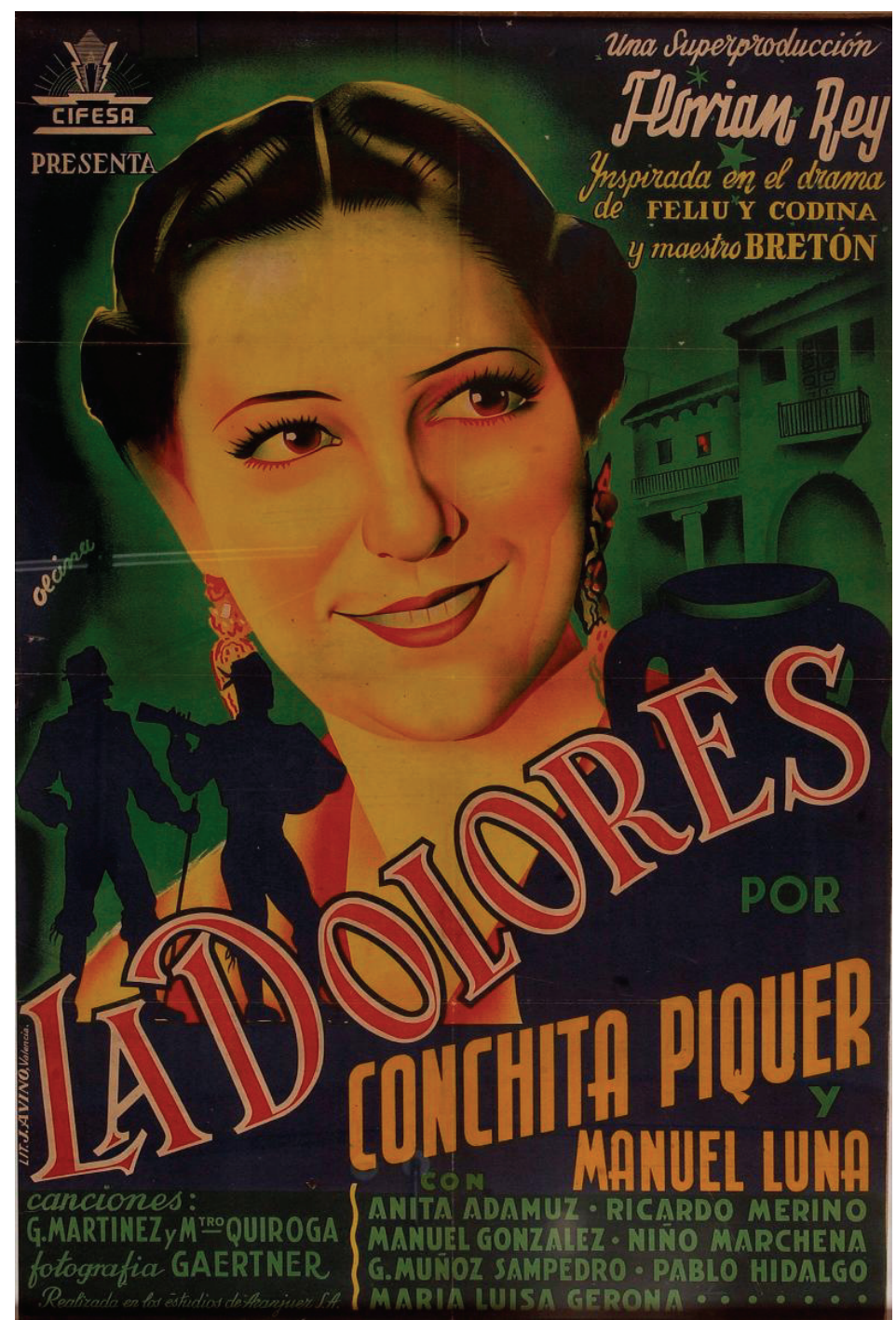

1. ANÁLISIS FORMAL

\subsection{DESCRIPCIÓN GENERAL}

- Título: La Dolores

- Autor: Olcina Rodilla, Jaime (1913 - 2002)

- Lugar: [Madrid]

- Publicación: CIFESA 
- Año: [ca. 1940]

- Imprenta:

- Lugar de impresión: Valencia

- Empresa gráfica: [Litografía] J. Aviñó

- Descripción Física:

- Hojas: 1

- Dimensiones (cm.): 101,5 x 68

- Técnica: Litografía

- Soporte: Papel

- Posición: Vertical

- Color: Color

- Restaurado: No

- Estado de conservación:

- Valoración: Excelente

- Observaciones: Conservado en un marco con cristal

\subsection{ISBD}

La DOLORES/ Olcina.- [Madrid]: CIFESA, [ca. 1940] (Valencia: [Litografía] J. Aviñó). - 1 cartel (1 hoja): litografía col.; 101,5 x 68 cm.

Nombre completo del autor: Jaime Olcina Rodilla

I. Olcina Rodilla, Jaime (1913 - 2002)

\section{ANÁLISIS DE CONTENIDO}

\subsection{TEXTO}

\subsubsection{Personas}

- Cartelista:

- Firma del cartelista: Olcina 
- Detalle de la firma:

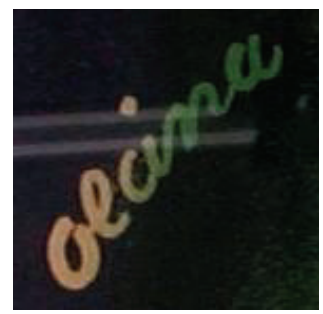

- Equipo técnico y artístico:

- Director: Florián Rey

- Intérpretes: Concha Piquer; Manuel Luna; Ana Adamuz; Ricardo Merino; Manuel González; Niño de Marchena; Guadalupe Muñoz Sampedro; Pablo Hidalgo; María Luisa Gerona

- Profesionales y técnicos: José Feliu y Codina (Argumento); Guadalupe Martínez del Castillo (Música); Manuel Quiroga (Música); Tomás Bretón (Música); Enrique Gaertner (Fotografía)

- Transcripción del equipo técnico y artístico: Una superproducción Florian Rey inspirada en el drama de Feliu y Codina y Maestro Bretón; Conchita Piquer; Manuel Luna; con Anita Adamuz; Ricardo Merino; Manuel González; Niño de Marchena; G. Muñoz Sampedro; Pablo Hidalgo; María Luisa Gerona; Canciones de G. Martínez y M $^{\text {tro }}$ Quiroga; Fotografía Gaertner

\subsubsection{Empresas}

- Distribuidora: CIFESA

- Estudios: Estudios de Aranjuez

- Imprenta: Litografía J. Aviñó

- Transcripción de las empresas: CIFESA presenta; Lit. J. Aviñó, Valencia; Realizada en los estudios de Aranjuez S.A.

\subsubsection{Eslogan}

- Eslogan: Una superproducción Florián Rey inspirada en el drama de Feliu y Codina y Maestro Bretón

- Tipo de eslogan: Frase de asiento (base-line) 


\subsection{IMAGEN}

\subsubsection{Descriptores}

- Onomásticos: Concha Piquer

- Temáticos: Trajes regionales, Balcón, Cantaor.

\subsection{LOGOTIPO}

- Distribuidora: CIFESA

- Detalle del logotipo:

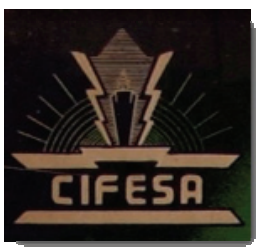

\subsection{RESUMEN}

Ocupando la práctica totalidad del cartel, se observa el plano medio de una mujer joven. La mujer es morena con ojos oscuros y parece tener el pelo recogido. Sus labios rojos muestran una amplia sonrisa y luce pendientes largos de color rojo y amarillo. La mujer es la actriz Conchita Piquer, que interpreta a "La Dolores" en la película publicitada.

Delante de la mujer, en primer término, aparece ocupando la mitad inferior derecha del cartel, la sombra negra de una vasija. De igual manera, delante de la mujer, en segundo término, aparece la sombra negra del plano general de dos cantaores. El cantaor de la izquierda se apoya en un bastón, mientras que el de la derecha toca una guitarra.

Tras la mujer, se observa en la mitad superior derecha el contorno negro de dos viviendas construidas sobre unos soportales con arcos y columnas. Una de las ventanas de las viviendas aparece iluminada levemente en color rojo.

El fondo del cartel es verde oscuro y negro, adornado con pequeñas estrellas verdes en la zona superior derecha, sobre las viviendas anteriormente citadas.

En la mitad inferior aparece formando una línea curva, el título de la película "LA DOLORES" en letras rojas de gran tamaño, bordeadas de beige y negro.

Bajo el título aparece, en letras naranjas de gran tamaño, el nombre de la actriz protagonista "CONCHITA PIQUER", precedido de la preposición "POR" en letras verdes de inferior tamaño. Debajo, el nombre de otro actor protagonista "MANUEL LUNA", precedido de la conjunción "Y" en letras vedes de inferior 
tamaño.

En el tercio superior derecho del cartel aparece el eslogan de la película en letras beige y amarillas, en el que se incluyen los nombres del director, del responsable del argumento y del responsable musical "Una superproducción FLORIAN REY Inspirada en el drama de FELIU y CODINA y maestro BRETON". El nombre del director "FLORIAN REY" destaca tipográficamente sobre el resto del texto.

En el tercio inferior izquierdo figuran en letras verdes los nombres de los músicos "canciones: G. Martinez y $\mathrm{M}^{\text {tro }}$ Quiroga" y el responsable de fotografía "fotografía GAERTNER”. A la derecha, separados por una línea naranja aparecen, en letras verdes y dispuestos en cuatro líneas, los nombres del resto del reparto "ANITA ADAMUZ", "RICARDO MERINO", "MANUEL GONZALEZ", "NIÑO MARCHENA", "G.MUÑOZ SAMPEDRO”, "PABLO HIDALGO” y "MARIA LUISA GERONA". Los nombres están separados por un punto verde y, tras la última actriz, aparecen siete puntos del mismo color.

En la mitad izquierda del cartel, se observa la firma del cartelista "Olcina".

En la esquina superior izquierda, aparece el logotipo de la distribuidora "CIFESA" seguido de la palabra "PRESENTA" en letras beige.

En el margen izquierdo, en posición vertical, se observa el nombre de la imprenta "LIT. AVIÑO Valencia".

En la parte inferior izquierda, en letras verdes de reducido tamaño, aparece el nombre de los estudios "Realizada en los estudios de Aranjuez S.A.".

\section{INFORMACIÓN COMPLEMENTARIA}

\subsection{INFORMACIÓN DE FECHAS}

- Fecha de producción: 1940

- Fecha de censura: 1940

- Fecha de estreno: 1940

\subsection{FICHA DE LA PELÍCULA}

- Título de la película: La Dolores

- Director: Florián Rey

- Intérpretes: Concha Piquer (Dolores); Manuel Luna (Melchor); Ana Adamuz (Gaspara); Ricardo Merino (Lázaro); Manuel González (Sr. Patricio); Niño de Marchena (sargento Rojas); Guadalupe Muñoz Sampedro (Sra. Sánchez); Pablo Hidalgo (mayoral); María Luisa Gerona (Catalina); Alfredo Hurtado (Miguel); Juan Calvo (Federico Sánchez); Nicolás Díaz Perchicot (don Simeón); Pilar Soler; Rafael Albaicín

- Profesionales y técnicos: José Feliu y Codina (Argumento); Florián Rey 
(Guión); Enrique Gaertner (Fotografia); Tomás Bretón (Música); Manuel Quiroga (Música); Guadalupe Martínez del Castillo (Música)

- Productora: CIFESA Producción

- Distribuidora: CIFESA

- Estudios: Estudios de Aranjuez

- Nacionalidad: Española

- Género: Drama

- Color: Blanco y negro

- Duración (min.): 101

- Argumento: A una posada de Daroca llega la diligencia que comunica varios pueblos de Aragón. Dolores, la criada del mesón, se entretiene hablando con su admirador Melchor, barbero del pueblo. Cuando acude a las apremiantes llamadas de la dueña, vierte la sopa en el vestido de la señora Sánchez, una viajera con muchos humos. Por tal motivo, Dolores entabla una violenta discusión con su ama, coge su hatillo se marcha en la diligencia, gracias a que Lázaro, un estudiante que regresa a su pueblo, se ofrece a pagarle el importe del viaje. Para cuando el carruaje llega a Calatayud, Lázaro ya sabe que Dolores no tiene familia ni lugar a donde ir y le ofrece la posibilidad de trabajar como sirvienta en la fonda de su tía. Al poco rato, Lázaro es recibido con grandes muestras de cariño por Gaspara, que se siente orgullosa de los progresos académicos de su sobrino, al que le costea los estudios. Gracias a su desparpajo, Dolores es admitida en la posada y desde el primer momento se impone su belleza y simpatía. Casi sin darse cuenta, Lázaro y Dolores empiezan a quererse, procurando que la señora Gaspara no se dé cuenta del naciente idilio. Entre los parroquianos de la fonda hay un lugareño formal y muy influyente, el señor Patricio, que se afana en agradar a Dolores. Por tal motivo dispone que la tradicional fiesta taurina se celebre en la plaza donde se ubica la posada. En pleno festejo, una de las improvisadas gradas se hunde y un becerro embiste a los accidentados. Lázaro se lanza a la plaza y consigue sujetar al bicho, pero sufre una cornada en el brazo. Dolores se erige en su enfermera permanente y la herida parece que nunca ha de tener cura... Mientras tanto, en Daroca, un despechado Melchor dedica a Dolores una copla insidiosa que se extiende con rapidez por toda la comarca. Cuando Dolores la oye por primera vez, consigue hábilmente que Melchor, que ha acudido a las fiestas de Calatayud, confiese que es el autor de la infame canción. Ciega de ira, le rompe una guitarra en la cabeza. Mozos de todas partes acuden al mesón de la Gaspara atraídos por lo que dice la jota y deseosos de conocer a su protagonista. Aunque a costa de la dignidad de Dolores, el negocio prospera. Por el lugar se deja caer también el sargento Rojas, que enseguida se percata de la calumnia y se pone al habla con Melchor a fin de que pida perdón a la mujer agraviada. Arrepentido, cambia la letra de la jota para restituir a Dolores su buena fama. Entre tanto, el curso ya ha 
empezado y Lázaro sigue con su brazo en cabestrillo; en realidad, un truco para quedarse más tiempo junto a Dolores. Pero Gaspara 1o descubre y, acto y seguido, manda a su sobrino a Tarazona para continuar sus estudios. En cuanto la diligencia sale del pueblo, Lázaro pide que se detenga y se apea. Al rato, Dolores recibe el recado de que Lázaro la espera esa noche después de la fiesta. Comienza el jolgorio con una farsa de cierto sabor religioso, en la que Melchor desempeña el papel de diablo. Como es natural, se le permiten diabluras y en una de éstas trepa hasta la azotea donde está Dolores e intenta abrazarla. Ella pide ayuda a Lázaro, que acude en su defensa. En un momento de la pelea, Melchor pierde el equilibrio y cae desde el tejado. Ante el asombro de la concurrencia, el pobre diablo yace muerto sobre el pavimento de la plaza en fiestas (Heinink y Vallejo, 2009).

- Notas: Premio del Sindicato Nacional del Espectáculo a la Mejor Película; Basada en la zarzuela La Dolores de José Feliu y Codina y Tomás Bretón.

\section{CONCLUSIONES}

Atendiendo a su definición, se puede decir que un cartel de cine es un anuncio publicitario, impreso a una cara, en una lámina generalmente de papel y de gran tamaño, compuesto por imagen, texto o por ambos a la vez y diseñado para promocionar una película cinematográfica con el fin de informar sobre ella e influir en el público para su visionado.

Por poseer una intención comunicativa propia y unas características específicas, el cartel cinematográfico deberá ser tratado de forma autónoma y no como un derivado complementario de la película que publicita aunque no conviene olvidar la relación que la une a ésta desde su génesis así como la relación que tiene con otros documentos que integran también el patrimonio cinematográfico (programas de mano, fotografías, etc.).

Actualmente, los trabajos realizados en bibliotecas y filmotecas no tratan de manera específica el análisis de contenido del cartel cinematográfico, por lo que es necesario profundizar en un modelo que se ocupe de su completo tratamiento. En este sentido, el análisis de contenido debe combinar los métodos tradicionales de indización y resumen con la descripción de los diferentes elementos que organizan la estructura semiótica mixta de la publicidad planteada por Adam y Bonhomme y que centra su atención los tres constituyentes del discurso publicitario: la imagen, el texto y el logotipo.

El tratamiento documental completo del cartel cinematográfico ha de contemplar, además, la descripción formal basada en estándares reconocidos y la descripción de contenido, para la que se utilizarán las técnicas tradicionales de indización y resumen combinadas con el análisis de los componentes del cartel (imagen, texto y logotipo). 
En definitiva, la catalogación del cartel de cine debe estructurarse en dos partes: análisis formal y análisis de contenido. El análisis formal del cartel cinematográfico debe recoger información de título y mención de responsabilidad, edición si la contempla, publicación, descripción fisica, estado de conservación y notas. Por otro lado, el análisis de contenido debe registrar: 1. información relativa al texto: personas que aparecen o son mencionadas en el cartel (cartelista, equipo técnico y artístico), empresas (productora, distribuidora, estudio e imprenta) y eslogan; 2. información relativa a la imagen representada mediante descriptores geográficos, onomásticos y temáticos; 3. información de los logotipos que aparecen en el cartel; 4. un resumen descriptivo de todos los elementos del cartel de cine aportando una visión integradora de su composición.

\section{REFERENCIAS BIBLIOGRÁFICAS}

ADAM, J. M., Y BONHOMME, M. (2000). La argumentación publicitaria: retórica del elogio y de la persuasión. Madrid: Cátedra.

ALCÁCER GARMENDIA, J. A. (1991). El mundo del cartel. Madrid: Ediciones Granada.

Biblioteca Nacional de España. (2013). ISBD. Recuperado de http://www.bne.es/es/Inicio/Perfiles/Bibliotecarios/NormasInternacionales/IS BD [Consulta: 27/08/2013].

BORDWELL, D., STAIGER, J. Y THOMSON, K. (1997). El cine clásico de Hollywood: estilo cinematográfico y modo de producción hasta 1960. Barcelona: Paidós.

Cineteca di Bologna. (2011). Linee guida per catalogazione del corredo grafico e promozionale di cinema. Recuperado de http://www.cinetecadibologna.it/files//archivi/grafica/linee/index.htm [Consulta: 07/03/2011].

CLAUSÓ GARCÍA, A. (2001). Manual de análisis documental: descripción bibliográfica. Madrid: EUNSA.

COLLADO ALONSO, R. (2012). El cartel de cine en la transición española: realidad y cambio social [Tesis doctoral]. Universidad Complutense de Madrid.

Decreto de 13 de febrero de 1953. (22 de marzo de 1953). Por el que se organiza la Filmoteca Nacional. Boletín Oficial del Estado, 81, 1499.

Decreto de 23 de diciembre de 1957. (20 de enero de 1958). Por el que se aprueba el Reglamento del Servicio del Depósito Legal. Boletín Oficial del Estado, 17, 104-106.

EDMONDSON, R. (2004). Filosofía y acceso a los archivos audiovisuales. París: UNESCO.

FERNÁNDEZ MELLADO, R. (2013). El cartel de cine español de posguerra (1939-1945): modelo de tratamiento documental (Tesis doctoral). Universidad Complutense de Madrid. 
Filmoteca Española. (2005). Filmoteca Española: cincuenta años de historia (1953 - 2003). Madrid: Filmoteca Española, Instituto de la Cinematografía y de las Artes Audiovisuales, Ministerio de Cultura.

Filmoteca Generalitat Valenciana. (1991). La imagen rescatada: recuperación, conservación y restauración del patrimonio cinematográfico (exposición que tuvo lugar en el Ateneo Mercantil de Valencia en junio de 1991). Valencia.

FOX, V. (2005). Análisis documental de contenido: principios y prácticas. Buenos Aires: Alfagrama.

GÓMEZ PÉREZ, F. J. (2002). La tipografía en el cartel cinematográfico: la escritura creativa como modo de expresión. Comunicación: revista internacional de comunicación audiovisual, publicidad y literatura, 1, 203216.

HEININK, J. B. y Vallejo, A. C. (2009). Catálogo del cine español. Volumen F3, Films de ficción 1931-1940. Madrid: Cátedra, Filmoteca Española.

IFLA. (2004). Requisitos funcionales de los registros bibliográficos: informe final. Madrid: Ministerio de Cultura.

Ley 23/2011 de 29 de julio de 2011 (30 de julio de 2011). Ley de depósito legal. Boletín Oficial del Estado, 182, 86716-86727.

Ley 55/2007 de 28 de diciembre de 2007. (29 de diciembre de 2007). [Ley del cine]. Boletín Oficial del Estado (BOE), 312, 53686-53701.

MARTÍNEZ DE SOUSA, J. (2004). Diccionario de bibliología y ciencias afines ( $3^{\mathrm{a}}$ ed.). Gijón: Trea.

MOLES, A. A. (1976). El afiche en la sociedad urbana. Buenos: Paidós.

MOLES, A. A. (ed.). (1985). La comunicación y los mass media. Bilbao: Mensajero.

NATANSON, B. O. (2001). Prints and Photographs Division. Recuperado de http://memory.loc.gov/ammem/awhtml/awpnp6/index.html [Consulta: 27/08/2013].

OTLET, P. (1996). El Tratado de Documentación: el libro sobre el libro: teoría y práctica. Madrid: Universidad de Murcia.

PERALES BAZO, F. (1999). El cartel cinematográfico. Junta de Andalucía, Conserjería de Cultura.

PERALES BAZO, F. (coord.). (2007). Cine y publicidad. Madrid: Editorial Fragua.

PÉREZ PERUCHA, J. (1986). Escaparates del espectáculo o indicadores del sentido. En Cine/impreso: cartelistas españoles de cine 1955/1985 (pp. 9-22) (exposición celebrada en 1986 en el Palacio Municipal de Exposiciones Kiosko Alfonso en colaboración con el Ayuntamiento de La Coruña). Madrid: Ediciones La Misma.

PICCO, P., y ORTIZ REPISO, V. (2012). RDA, el nuevo códico de catalogación: cambios y desafíos para su aplicación. Revista Española de Documentación Cientifica, 35(1), 145-173. 
PINTO, M. (2001). El resumen documental: paradigmas, modelos y métodos. Madrid: Fundación Germán Sánchez Ruipérez.

PINTO, M., Y GÁLVEZ, C. (1996). Análisis documental de contenido: procesamiento de información. Madrid: Síntesis.

Reglas de catalogación. (2010). Madrid: Ministerio de Cultura.

RODRÍGUEZ BRAVO, B. (2002). El documento: entre la tradición y la renovación. Gijón: Trea.

RODRÍGUEZ TRANCHE, R. (1994). El cartel de cine en el engranaje de "star system". Archivos de la Filmoteca, 18, 135-143.

RODRÍGUEZ TRANCHE, R. (1996). Pintar el aura. En Cine de papel: el cartel de cine en España (exposición celebrada en La Lonja, 25 junio- 18 agosto de 1996) (pp. 21-26). Zaragoza: Ayuntamiento, Servicio de Acción Cultural.

RUIZ PÉREZ, R. (1992). El Análisis Documental, bases terminológicas, conceptualización y estructura operativa. Granada: Universidad de Granada.

VALLE GASTAMINZA, F. del. (2007). Documentación Audiovisual. Recuperado de http://www.ucm.es/info/multidoc/prof/fvalle/tema12b.htm [Consulta: 31/08/2013].

WILLIS GARCÍA-TALAVERA, J. F. (2002). Los años dorados de Metro Goldwyn Mayer: los programas de mano. Madrid: Ediciones Tauro. 